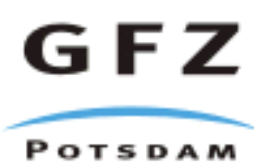

Originally published as:

Güntner, A., Bronstert, A. (2004): Representation of Landscape Variability and Lateral Redistribution Processes for Large-Scale Hydrological Modelling in Semi-Arid Areas. Journal of Hydrology, 297, 1-4, 136-161

DOI: 10.1016/j.jhydrol.2004.04.008 


\title{
Representation of landscape variability and lateral redistribution processes for large-scale hydrological modelling in semi-arid areas
}

\author{
Andreas Güntner ${ }^{\mathrm{a}, *}$, Axel Bronstert ${ }^{\mathrm{b}, \mathrm{c}, 1}$ \\ ${ }^{\mathrm{a}}$ GeoForschungsZentrum Potsdam (GFZ), Telegrafenberg, 14473 Potsdam, Germany \\ ${ }^{\mathrm{b}}$ Department of Geoecology, University of Potsdam, P.O. Box 601553, 14415 Potsdam, Germany \\ ${ }^{\mathrm{c}}$ Potsdam Institute for Climate Impact Research, P.O. Box 601203, 14412 Potsdam, Germany
}

Received 24 April 2003; revised 15 March 2004; accepted 1 April 2004

The spatial variability of landscape features such as topography, soils and vegetation defines the spatial pattern of hydrological state variables like soil moisture. Spatial variability thereby controls the functional behaviour of the landscape in terms of its runoff response. A consequence of spatial variability is that exchange processes between landscape patches can occur at various spatial scales ranging from the plot to the basin scale. In semi-arid areas, the lateral redistribution of surface runoff between adjacent landscape patches is an important process. For applications to large river basins of $10^{4}-10^{5} \mathrm{~km}^{2}$ in size, a multi-scale landscape discretization scheme is presented in this paper. The landscape is sub-divided into modelling units within a hierarchy of spatial scale levels. By delineating areas characterized by a typical toposequence, organised and random variability of landscape characteristics is captured in the model. Using runoff-runon relationships with transition frequencies based on areal fractions of modelling units, lateral surface and subsurface water fluxes between modelling units at the hillslope scale are represented. Thus, the new approach allows for a manageable description of interactions between fine-scale landscape features for inclusion in coarse-scale models. Model applications for the State of Ceará $\left(150,000 \mathrm{~km}^{2}\right)$ in the north-east of Brazil demonstrate the importance of taking into account landscape variability and interactions between landscape patches in a semiarid environment. Using mean landscape characteristics leads to a considerable underestimation of infiltration-excess surface runoff and total simulated runoff. Re-infiltration of surface runoff and lateral redistribution processes between landscape patches cause a reduction of runoff volumes at the basin scale and contribute to the amplification of variations in runoff volumes relative to variations in rainfall volumes for semi-arid areas.

(C) 2004 Published by Elsevier B.V.

Keywords: Landscape discretization; Semi-arid; Spatial scale; Variability; Lateral processes; North-eastern Brazil

\section{Introduction}

1.1. Landscape variability and hydrological processes in semi-arid areas

\footnotetext{
* Corresponding author. Tel.: +49-331-288-1535; fax: +49-331288-1570.

E-mail addresses: guentner@gfz-potsdam.de (A. Güntner), axelbron@rz.uni-potsdam.de (A. Bronstert).

${ }^{1}$ Tel.: +49-331-977-2548; fax: +49-331-977-2068.
}

River catchments exhibit spatial variability of landscape characteristics such as geology, topography,

0022-1694/\$ - see front matter (c) 2004 Published by Elsevier B.V. doi: $10.1016 /$ j.jhydrol.2004.04.008 
soils, land use and vegetation. These characteristics govern the partitioning of precipitation into runoff and evapotranspiration and contribute to defining the spatial distribution of soil moisture within the catchment. Soil moisture patterns, in turn, are a key factor in influencing runoff generation and the hydrological response of a catchment. This interaction of soil moisture and hydrological processes as a function of landscape variability affects both vertical and lateral water fluxes. Vertical fluxes occur by processes such as infiltration, percolation and evapotranspiration. Lateral fluxes are related to redistribution processes of surface runoff, water in the saturated and unsaturated soil zone or in the groundwater flowing roughly parallel to the terrain surface. Depending on whether vertical or lateral water fluxes dominate, Grayson et al. (1997) distinguished between local and non-local control on soil moisture patterns. Concerning the variability of landscape characteristics and related processes, a distinction can be made between organised and random variability (Seyfried and Wilcox, 1995; Blöschl and Sivapalan, 1995). In the case of organised variability, a predictable regularity in the spatial distribution of a variable such as soil moisture can be observed, e.g. as a function of topography. Such a catena or toposequence concept of relating landscape characteristics to the topographic location goes back to Milne (1935a,b), cited by Birkeland (1999). There, a specific sequence of soils along hillslopes was proposed, where each soil shows a distinct relationship to the soils upslope and downslope for a variety of geo-morphologic, pedological and hydrological reasons. Landscape variability is generally recognized at different spatial scales from the profile to the catchment scale (Puigdefabregas et al., 1999 and examples below). These scale levels can be described as interlinked levels within a nested hierarchy where landscape elements at different levels are related to higher and lower level features, thereby defining the characteristic patterns and the functional behaviour of the landscape (see a recent example of the hierarchy concept by Wielemaker et al. (2001)).

In a semi-arid environment, which is often characterised by high rainfall intensities and sparse vegetation cover, a Horton-type infiltration-excess mechanism producing surface runoff is generally considered to be the dominant runoff generation process at the local (point) scale (Yair and
Lavee, 1985). The process is enhanced by the development of crusted soil surfaces with low hydraulic conductivities (see a recent review by Patrick (2002)). Saturation-excess runoff is usually considered to be of less importance. However, it may occur for some specific conditions, as, for instance, during the rainy period in valley bottoms (Ceballos and Schnabel, 1998; Gresillon and Taha, 1998) or on soils of high infiltration capacity but low storage capacity, e.g. shallow soils above bedrock of low conductivity (Cadier, 1993; Martinez-Mena et al., 1998; Puigdefabregas et al., 1998). Beyond the local scale, the runoff response at the hillslope or at the catchment scale has frequently been shown to be influenced by the variability of landscape characteristics An important aspect of patch-scale variability in semi-arid areas is introduced by the neighbourhood of vegetated and bare soil surfaces, as observed in many dryland vegetation types (see summary of examples in Klausmeier, 1999; Reid et al., 1999). This patchiness influences, on the one hand, total evapotranspiration rates of the land surface by the interaction of energy and momentum fluxes from bare and vegetated patches (Boulet et al., 1999). On the other hand, the patchiness gives rise to redistribution of runoff and associated sediments and nutrients, with bare soil surfaces tending to act as source areas of surface runoff and vegetated patches as sink areas, receiving runon from bare soil surfaces for re-infiltration (Puigdefabregas and Sanchez, 1996; Bromley et al., 1997; Reid et al., 1999; Valentin and d'Herbès, 1999; Cammeraat, 2002). Extending to the scale of hillslopes or small catchments, additional variability of landscape characteristics influences the runoff redistribution. Characteristic sequences of surface types in terms of vegetation cover, soils and surface crusts with variable infiltration characteristics were shown for hillslope transects in semi-arid Africa by Perrolf and Sandström (1995), Bromley et al. (1997) and D'Herbès and Valentin (1997) or for semi-arid Spain (Nicolau et al., 1996). Bergkamp (1998) distinguished in a hierarchical way five spatial scale levels by characteristic discontinuities in the geomorphological and soil properties, ranging from the terracette level, via various hillslope scales to the catchment scale. For semi-arid north-eastern Brazil, Cadier et al. (1996) illustrated the importance of varying soil types along a hillslope catena where 
surface runoff generated on soils with low infiltration capacities can directly re-infiltrate in a downslope strip of soils with high infiltration capacity. Decreasing runoff coefficients with increasing slope length due to a large variability of soil characteristics were also observed by Bonell and Williams (1986) and Puigdefabregas et al. (1998) for semi-arid and by Van de Giesen et al. (2000) for sub-humid environments. A distinction between slope segments as runoff source areas and colluvial footslope areas or alluvial deposits in the valley bottoms as sink areas for runon was highlighted for semi-arid areas by Yair and Lavee (1985), De Boer (1992), Peugeot et al. (1997), Ceballos and Schnabel (1998) and Puigdefabregas et al. (1998). These studies also demonstrate that discontinuities of hydrological pathways can exist between runoff generating areas and the channel network or the catchment outlet particularly for dry conditions (Fitzjohn et al., 1998; Bergkamp, 1998; Cammeraat, 2002). With increasing catchment area, the importance of transmission losses of runoff that already became channel flow by re-infiltration into the channel bed also increases. This process has often been referred to as one reason for decreasing runoff coefficients (Cadier et al., 1996) and an increasing non-linearity of the runoff response (Goodrich et al., 1997) with increasing basin area in small semi-arid catchments. All examples show that runoff at the hillslope or small catchment scale in semi-arid areas is in general markedly less than what can be expected by simply summing up the contributions of individual landscape patches. Redistribution processes between the patches with re-infiltration of surface runoff can be of high importance.

While the outline so far focused on surface runoff, lateral subsurface flow processes may also be relevant although they are usually not considered in semi-arid environments (for an overview and a critique see Beven, 2002). Lateral subsurface flow in the semi-arid is generated for specific conditions, for instance in the presence of soil pipes or other macropores (Torri et al., 1994; Sandström, 1996), during the development of a perched water table in wet periods (Wilcox et al., 1997; Van de Giesen et al., 2000; Chamran et al., 2002) or during saturation of alluvial zones next to the main channel (Ceballos and Schnabel, 1998).

\subsection{Model representation of landscape variability} and lateral fluxes

In hydrological models it is required to account for the spatial variability of landscape characteristics and for the processes as those mentioned above if the hydrological response of a catchment should be adequately represented. Woolhiser et al. (1996), Merz and Plate (1997), Bronstert and Bárdossy (1999) and Merz et al. (2002), for instance, demonstrated the importance of using spatially variable instead of uniform mean distributions of soil moisture or infiltration parameters for modelling surface runoff generation, also stressing the importance of organization in variability. Flerchinger et al. (1998) showed the need to sub-divide a semi-arid catchment into different landscape units according to major vegetation types in order to correctly estimate total evapotranspiration particularly under conditions when water is a limiting factor. In particular, a model taking into account spatial variability is required for applications which intend to assess the effect of changing boundary conditions or of disturbances, like land cover or climate change. A lumped catchment model, although it may well capture the overall catchment dynamics in terms of the hydrograph at the outlet (Chiew et al., 1993; Ye et al., 1997), will hardly be able to incorporate such changes which affect individual processes or parts of the total catchment area only, due to the loss of physical foundation of basin-average model parameters. Additionally, a spatially distributed model representation of the catchment is obviously required where distributed results are to be given as one objective of the model application, for example when soil moisture patterns have to be linked to a crop or vegetation model.

Several approaches have been taken to incorporate landscape variability into hydrological models. One is the use of complex fully distributed models such as SHE (Abbott et al., 1986), IHDM (Beven et al., 1987) or HILLFLOW (Bronstert and Plate, 1997). While including also explicitly lateral surface and subsurface fluxes and their redistribution, data and computational requirements prevent these models from being applied for larger catchments (Bronstert, 1999).

An alternative approach is to capture the variability of any essential catchment characteristic 
by a distribution function without any explicit spatial assignment of areas of different hydrological characteristics, as, for instance, for the soil moisture deficit or infiltration capacity (Beven and Kirkby, 1979; Zhao et al., 1980; Wood et al., 1992). These approaches usually give lumped results at the catchment scale. A limitation is that lateral water redistribution among different parts of the study area, i.e. among different parts of the distribution, cannot be represented in the model. An exception is the TOPMODEL approach of Beven and Kirkby (1979), where the distribution of a topographic index also implicitly takes into account the effect lateral subsurface flow on soil moisture in downslope positions.

Another widely used strategy to capture landscape variability in hydrological models is by defining areas of an assumed similar hydrological response, called hydrological response units (Leavesley et al., 1983) or hydrotopes (Becker and Nemec, 1987). The crucial points of this approach lie, first, in the definition of a hydrological quantity of interest according to which this similarity is to be defined. Secondly, they lie in the selection of those landscape characteristics, heterogeneities and related hydrological processes that ensure that the assumption of similarity of the hydrological response within one of the accordingly delineated modelling units is valid. This selection can be based on expert knowledge, the perception of the hydrological behaviour of the study area and on comparative studies, which evaluate the performance of models for different ways of delineating the hydrotopes (Becker and Braun, 1999; Wooldridge and Kalma, 2001). In most cases, the discretization of the landscape is done with regard to similarity of vertical hydrological processes, i.e. hydrotopes being similar in terms of infiltration, percolation and evapotranspiration fluxes (Kite and Kouwen, 1992; Krysanova et al., 1998; Becker and Braun, 1999; Gurtz et al., 1999; Wooldridge and Kalma, 2001). This is usually achieved by intersecting physiographic data such as elevation, soils, vegetation and land use. An essential shortcoming of this approach is that interactions between different hydrotopes, e.g. in terms of redistribution of runoff components between them, are generally not taken into account. One reason is that in the case of irregularly shaped hydrotopes, a routing scheme that relates them in the sense of upslope-downslope relationships cannot be clearly defined. Particularly in larger-scale models, another reason is that hydrotopes are often too large in size to resolve these hillslope-scale patterns and processes. In both cases, runoff components generated in each hydrotope are simply summed up to give the total basin response, often after passing one or more linear or non-linear conceptual storages. In other words, a problem associated with a two-domain scheme as recommended by Becker and Nemec (1987) with different ways of discretizing the landscape for the domain of vertical processes and lateral processes, respectively, is that it may be difficult to sample patches, once defined with respect to a similar behaviour of vertical water fluxes, to give another type of patches with similarity in lateral function. A different way, presented by Uhlenbrook and Leibundgut (2002), is to structure catchments directly into hydrological functional units as derived from experimental investigations, where each unit is characterized by distinct dominating runoff generation processes which may also include lateral processes. Each unit is accordingly represented by a specific model conceptualisation. Another approach where hydrologically similar units were defined in terms of both vertical and lateral processes was given by Karvonen et al. (1999).

Exceptions of hydrotope-based models where interactions between the modelling units are accounted for are WATBAL (Knudsen et al., 1986), the PRMS-based approach of Flügel (1995) and ARC/ EGMO (Becker et al., 2002). In these examples, an additional criteria for the classification of hydrotopes is their location within different topographic zones along hillslopes. By this way, subsurface flow can be routed between storages of different topographic position. In WATBAL and ARC/EGMO also surface runoff can be redistributed among downslope areas and may re-infiltrate there if sufficient storage capacity exists. A similar grid-based approach, which considers the interaction of lateral flow among cells with different soil-vegetation combinations has been presented by Schumann et al. (2000). However, studies which analyse the applicability of such landscape discretization schemes for large catchments with regard to the effect of variability and interaction between modelling units are rare, in particular in the case of semi-arid areas. 
In view of the above capabilities and limitations of existing response unit approaches, the purpose of this study is to develop a process-oriented modelling framework that includes an appropriate definition of spatial modelling units to capture landscape variability and related dominant vertical and lateral processes in large catchments. The focus is on model applications in semi-arid environments with the objective of long-term water balance studies and global change analysis, e.g. assessing the effect of climate variability and climate change on runoff and water availability. The approach should be applicable to large geographic regions (about $10^{3}-10^{5} \mathrm{~km}^{2}$ in size). Thus, a main question is how to efficiently link the final scale of interest of model applications with the process scales including the local and hillslope scale. In addition, this question has to be seen in context of limited data availability and resolution, as is often found for large semi-arid areas. This paper presents a spatial model structure and its process formulations and applies the model to a large semi-arid area $\left(148,000 \mathrm{~km}^{2}\right)$. The effects of representing landscape variability and lateral redistribution processes on runoff and water balance simulations and related parameter sensitivities are analysed.

\section{Spatial model structure and process description}

\subsection{General features}

The hydrological model WASA (Model of Water Availability in Semi-Arid Environments) is a deterministic model for continuous simulation, composed of process-oriented conceptual approaches. Model formulations are used that basically do not need calibration of their parameters, as they can be estimated from physiographic data. The modelling timestep is usually one day, but for small-area applications an hourly resolution can be used. A detailed description of the model is given by Güntner (2002). In order to capture the influence of the spatially variable landscape characteristics on soil moisture patterns and runoff generation, a hierarchical top-down discretization scheme is used in WASA for structuring the landscape into modelling units (Fig. 1). The hierarchy comprises six spatial scale levels ranging from the entire study area (e.g. a river basin 433 of about $10^{4}-10^{5} \mathrm{~km}^{2}$, not represented in Fig. 1) to 434 the soil profile. Landscape discretization at scales 435 smaller than sub-catchments (Levels 2-5 in Fig. 1) 436 is based on the SOTER concept (Soil and Terrain 437 Digital Database) (Oldeman and van Engelen, 1993). 438 This approach basically establishes a way to structure $\quad 439$ the landscape according to terrain and soil attributes at $\quad 440$ different spatial scale levels, recognizing the 441 which evolve by physical and biological processes 443 through time. The SOTER concept has been modified 444 and extended for hydrological purposes in this study. 445 The specific features and processes representations at 446 each scale level are described in the following 447 paragraphs. 448

\subsection{Catchment (Scale level 1)} catchments averaging $10^{3} \mathrm{~km}^{2}$ in area (Level 1 in Fig. 1) which are linked via the river network. These catchments typically represent the basic units for water resources management. Alternatively, grid cells can be used as the basic unit. At this level of the spatial hierarchy, the processes of runoff routing in the river network are simulated, including abstractions by water use and evaporation from the river, runoff retention in reservoirs and reservoir water balance. The water balance of large reservoirs is calculated explicitly. Small reservoirs and farm dams, which can be widespread in semi-arid areas, are represented by their distribution among different reservoir classes, using simplifying assumptions on the mean water balance for each class and on the location of the reservoirs in the catchment and relative to each other (Güntner et al., 2004). Runoff routing in the river network is represented by a simple linear response function depending on flow length and average slope of the main river in a sub-basin (Bronstert et al., 1999). Withdrawal water use is taken into account by a model-based assessment of water use in various sectors (irrigation, livestock, domestic, industrial and tourist water use) (Döll and Hauschild, 2002) and is directly coupled to river flow and reservoir volumes in WASA (Bronstert et al., 2000). occurrence of specific terrain-soil relationships 442

The entire study area is sub-divided into 453 


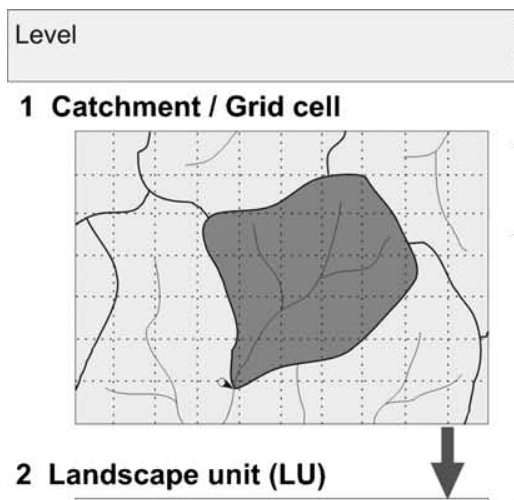

Polygons with geographically referenced location

Similarity of

- major landform

-general lithology

-soil associations

-toposequences

3 Terrain component (TC)

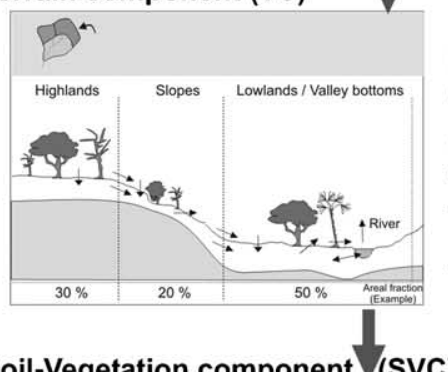

Fraction of area of landscape unit (no geographic reference)

Similarity of

-slope gradients

-position within

toposequence

-soil associations

4 Soil-Vegetation component (SVC)
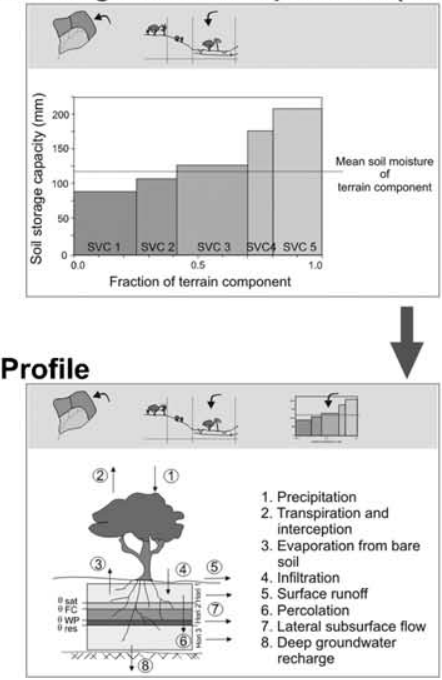

Fraction of area of terrain component

Characterized by specific combination of

-Soil (sub-)type

-Vegetation / land cover

class

Representative profile of soil-vegetation component

-Several soil horizons of variable depth

-Lower limit by depth of

root zone or bedrock
Function

Fig. 1. Hierarchical multi-scale scheme for structuring river basins into modelling units in WASA. 


\subsection{Landscape unit (Scale level 2)}

Within catchments, so-called landscape units (LUs) (Fig. 1, Level 2) are delineated. They cover areas that are similar in underlying lithology and bedrock characteristics and in the general form of the land surface, i.e. the type of dissection of the landscape by valleys in terms of elevation differences between valley bottoms and hilltops and in terms of the hillslope length. LUs are also characterised by a typical toposequence, i.e. by a certain hillslope catena which may be associated in its different topographic parts with a specific soil and vegetation association (i.e. a group of different soil and land use types). These features of similarity within a LU are assumed to imply similarity in terms of the variability of vertical hydrological processes and similarity of lateral processes. This includes the structure of water flux redistribution between patches, along hillslopes and by transmission losses in the valley bottoms. As a result, a specific spatial pattern of soil moisture can be expected within a LU. Taken as a whole, LUs are considered to be homogeneous in terms of their overall hydrological response at the landscape scale. In this sense, they can be called hydrotopes. However, LUs are not areas of quasihomogeneous characteristics as in the classical meaning of hydrotopes, but are similar in terms of their sub-scale variability of landscape characteristics and of hydrological state variables. The runoff volumes generated in each LU of a catchment or grid cell are added to give the total response of the catchment.

\subsection{Terrain component (Scale level 3)}

For the description of organised variability of landscape characteristics within LUs, LUs are sub-divided into terrain components (TCs) at the next smaller scale of the hierarchy (Fig. 1, level 3). Each LU is composed of, at most, three TCs, representing high-lands, slopes and valley bottoms, respectively. It is assumed that by using these three zones, the most important differences of terrain, soil and vegetation characteristics within the catena can be captured. Each TC is thus characterised by a specific mean slope gradient, its topographic position relative to other TCs within the toposequence and by the occurrence of a specific soil type or soil association and vegetation class. The number of TCs in a landscape unit can be reduced to two or one if significantly different topographic zones within the LU cannot be distinguished. TCs are represented by their fraction of area within the LU instead of their exact geographic location. This is due to limited data availability in the coarse-scale application where the low resolution of terrain data usually does not allow to resolve these hillslope-scale features explicitly.

The interaction of surface and subsurface lateral flow components from upslope topographic zones with those at downs-lope position, including re-infiltration and return flow, is represented in a simplified manner. Surface runoff $Q_{\mathrm{TC}, x}$ generated in any terrain component $x$ is separated into (1) flow entering any downslope terrain component $y$ as runon that is available for re-infiltration, and (2) into remaining flow that goes directly into the river and leaves the LU without being subject to transmission losses. The percentages of flow among these two components are assumed to be proportional to the respective areal fractions of TCs within the $\mathrm{LU}\left(a_{\mathrm{TC}, x}\right.$ or $\left.a_{\mathrm{TC}, y}\right)$ (Eqs. (1) and (2)). A TC which makes up a larger fraction of the total area of the LU is assumed to potentially retain a larger fraction of runoff that originates from upslope areas than a TC with a smaller areal fraction. (The actual volume of re-infiltration depends on the soil types and the antecedent moisture content, see Chapter 2.6).

$R_{\mathrm{TC}, y}=\sum_{x=1}^{y-1}\left(Q_{\mathrm{TC}, x} \frac{a_{\mathrm{TC}, y}}{\sum_{x}^{m} a_{\mathrm{TC}, x}}\right)$
$R_{\text {river }}=\sum_{x=1}^{m}\left(Q_{\mathrm{TC}, x} \frac{a_{\mathrm{TC}, x}}{\sum_{x}^{m} a_{\mathrm{TC}, x}}\right)$

$x$ in Eqs. (1) and (2) is the index of a TC which is runoff source area of flow to be redistributed, $y$ is the index of a TC which is runoff sink area of redistributed flow. The values of both $x$ and $y$ are confined to the range 1 (for the TC of highest topographic position) to $m$ (TC with lowest topographic position), where $m$ is the number of 


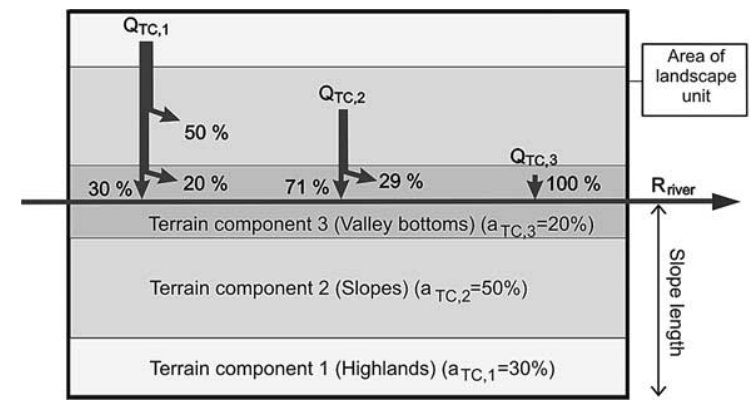

Fig. 2. Simplified scheme of lateral redistribution of surface water fluxes between terrain components.

TCs within a landscape unit with a maximum of $m=3$ (see above). $R_{\mathrm{TC}, y}$ in Eq. (1) is the total inflow from all upslope TCs $x$ that is received by terrain component $y . R_{\text {river }}$ in Eq. (2) is the inflow into the river from all TCs in the landscape unit. Consider Fig. 2 as an example of flow redistribution. From the total surface runoff generated in the highlands $\left(Q_{\mathrm{TC}, 1}\right)$, $50 \%$ are attributed as runon to the slope area $(\mathrm{TC}, 2)$ which has an areal fraction of $50 \%$ in the $\operatorname{LU}\left(a_{\mathrm{TC}, 2}\right)$, and $20 \%$ of the total flow is attributed to the valley bottoms (TC,3) with $a_{\mathrm{TC}, 3}=20 \%$. The remaining $30 \%$ of surface runoff from the highlands becomes directly river runoff. In addition, the valley bottoms receive $20 / 70 \times 100=29 \%$ of the surface runoff generated in the slope area $\left(Q_{\mathrm{TC}, 2}\right)$ as runon (corresponding to the areal fraction of the valley bottoms within the total area of slopes and valley bottoms). Surface runoff from the valley bottoms $\left(Q_{\mathrm{TC}, 3}\right)$ is added directly to river runoff.

Eqs. (1) and (2) apply to the redistribution of surface runoff only. In the case of lateral subsurface flow, $Q_{\mathrm{TC}, x}$ is completely attributed as inflow to the next downslope TC. Lateral subsurface flow from the lowest TC becomes river runoff. Both surface and subsurface inflow to a TC from upslope areas is partitioned between the various soil-vegetation components of this $\mathrm{TC}$ weighted in proportion to their areal fractions in the TC (Chapter 2.5).

\subsection{Soil-vegetation component (Scale level 4)}

In order to describe the heterogeneity of soil and vegetation characteristics and, thus, of soil moisture within TCs, each TC is further sub-divided into soil-vegetation components (SVCs) at the next smaller spatial scale (level 4 in Fig. 1). Each SVC is a modelling unit with a specific combination of a soil type and a land cover class (similar to the classification used by Schumann et al., 2000). Thus, the number of SVCs in a TC is given by the number of existing soil-vegetation combinations. SVCs are represented by their fraction of area within the TC without exact geographic reference. The spatial distribution of SVCs within a terrain component and the location of SVCs relative to each other is assumed to be non-organised, i.e. SVCs are modelled as a randomly distributed mosaic of patches (in contrast to the clumped depiction used for simplicity of drawing in Figs. 3 and A1). Lateral redistribution of surface and subsurface flow between SVCs is taken into account in WASA. For each SVC, the generated surface runoff $Q_{\mathrm{SVC}, x}$ is separated into (1) flow to all other SVCs of the same TC and into (2) flow $Q_{\mathrm{TC}, x}$ to a TC of lower topographic position or to the river. As for the redistribution among TCs (see Chapter 2.4), flow redistribution between the different SVCs (or, in other words, the transition frequencies of water fluxes between the spatial units) is in proportion to the areal fraction of SVCs within each TC $\left(a_{\mathrm{SVC}, v}\right.$ or $\left.a_{\mathrm{SVC}, z}\right)$ (Fig. 3). SVCs with a larger areal fraction receive more runon from other SVCs than SVCs with a smaller areal fraction (Eq. (3)). Similarly, the percentage of runoff transferred to a lower TC or directly to the river is larger for a SVC with a larger areal fraction (Eq. (4)).

$R_{\mathrm{SVC}, z}=\sum_{v=1, v \neq z}^{n}\left(Q_{\mathrm{SVC}, v} a_{\mathrm{SVC}, z}\right)$

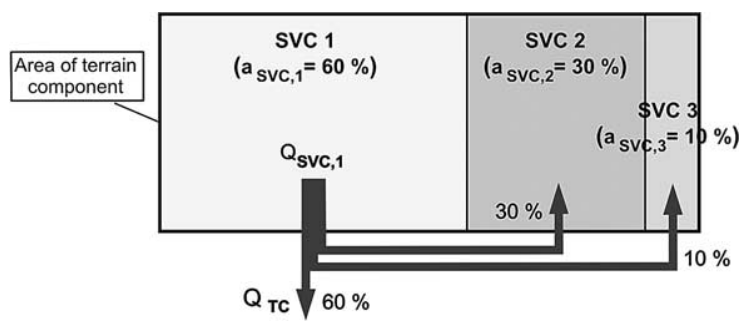

Fig. 3. Simplified scheme of lateral redistribution of surface and sub-surface water fluxes between soil-vegetation components. Example for a terrain component composed of three SVCs and for SVC, 1 as source area of lateral flow components. 
$Q_{\mathrm{TC}, x}=\sum_{v=1}^{n}\left(Q_{\mathrm{SVC}, v} a_{\mathrm{SVC}, v}\right)$

$v$ in Eqs. (3) and (4) is the index of a SVC which is runoff source area of flow to be redistributed, $z$ is the index of a SVC which is runoff sink area of redistributed flow. $n$ is the total number of SVCs in a TC. $R_{\mathrm{SVC}, z}$ in Eq. (3) is the total inflow from all other SVCs $v$ in TC $x$ that is received by soil-vegetation component $z$. Eqs. (3) and (4) apply for both surface and sub-surface runoff. In the case of surface flow, in receiving SVCs the runon is added as input to the infiltration routine (see Chapter 2.6). In the case of subsurface flow, lateral inflow into receiving SVCs is associated primarily with soil horizons at similar depths as those in the source area. If a soil profile is too wet or too shallow to absorb all incoming lateral subsurface flow, the remaining flow volume becomes surface runoff (return flow).

In addition, for each SVC a piece-wise linear distribution function, a simplification of Zhao et al. (1980), is used to describe the varying soil water storage capacity within the SVC. This distribution defines the fraction of the SVC that can generate saturation-excess surface runoff for a given mean soil moisture of the SVC.

\subsection{Profile (Scale level 5)}

At the smallest scale of the hierarchy (level 5 in Fig. 1), each soil-vegetation component is described by a representative soil profile. The number of soil horizons can be freely chosen and can vary between the SVCs in WASA. The lower boundary of the profile is usually set to the depth of the bedrock. Thus, nearsurface groundwater bodies can develop above the bedrock or a less permeable horizon and can generate lateral subsurface flow. If the bedrock is too deep below the terrain surface to influence surface processes, the lower boundary is set to the depth of the root zone. The water balance of the profile is calculated including vertical processes (infiltration, percolation, evapotranspiration) and lateral flow processes (from/to TCs of adjacent topographic position, and from/to SVCs within the same terrain component). The details of process modelling in WASA with emphasis on the quantification of lateral flow volumes are given in
Appendix A. In Appendix B, the temporal sequence of process representation within a timestep is explained.

\section{Study area and material}

\subsection{Study area of Ceará, North-Eastern Brazil}

The study area for an example application of WASA is the Federal State of Ceará $\left(148,000 \mathrm{~km}^{2}\right)$ in the semi-arid tropical north-east of Brazil (Fig. 4). Details on natural and socio-economic conditions of the area are given in Gaiser et al. (2003a). Ceará has recurrently been affected by droughts which caused serious economic losses and social impacts like migration from the rural regions. Mean annual precipitation is about $850 \mathrm{~mm}$, with more than $1500 \mathrm{~mm}$ in some mountainous regions close to the coast to less than $600 \mathrm{~mm}$ in the dry interior (Sertão). Rainfall is concentrated within a rainy season of about five months (January-May). Interannual rainfall variability is high with a coefficient of variation $C_{\mathrm{v}}$ of annual rainfall of 0.36 . Potential evaporation amounts to about $2100 \mathrm{~mm}$. About $80 \%$ of the study area is characterised by crystalline bedrock and usually shallow soils. In these areas, a xerophytic thorn-bearing woodland, mainly deciduous in the dry season, is the dominant natural vegetation type (Caatinga). The main agricultural use is extensive cattle farming and subsistence farming of mainly beans and maize. River flow in the study area is

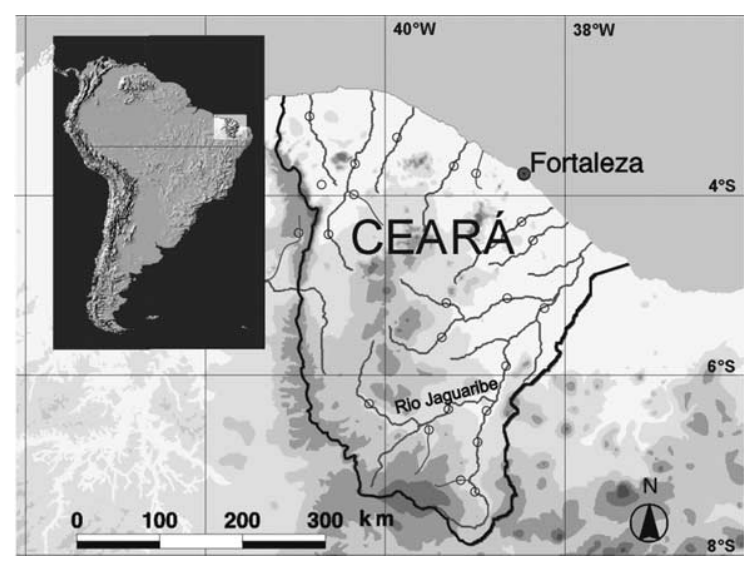

Fig. 4. Study area Ceará in North-East Brazil with main river network and location of gauging stations (empty circles). 
intermittent under natural conditions, including the largest river, Rio Jaguaribe, with a basin area of $74,000 \mathrm{~km}^{2}$. Mean annual runoff is $10-20 \%$ of annual rainfall. The $C_{\mathrm{v}}$ of annual discharge is generally above 1.0. Surface water provides the largest part of the water supply. More than 7000 dams exist in the study area with a total storage capacity of about $12.5 \times 10^{9} \mathrm{~m}^{3}$ (Frischkorn et al., 2003). River flow below large reservoirs is perennialised.

\subsection{Climate and hydrology data}

Climate data with daily resolution for this study covered the period 1960-1998 for precipitation, air temperature, relative humidity, wind velocity and short-wave radiation. Precipitation data were based on time series of 403 stations, of which, on average 200 were simultaneously available at each timestep. Interpolation was done to cells of a 10 by $10 \mathrm{~km}$ grid, using ordinary kriging with day-specific variograms. Also the other climate elements were interpolated to the grid cells, which were used as the basic spatial units (level 1 in Fig. 1) in the model application. Monthly discharge time series of variable length (7-31 years in the period 1960-1998) from 23 gauging stations were available (Fig. 4), partly provided by the Global Runoff Data Centre (GRDC, D-56002 Koblenz, Germany).

\subsection{Landscape data}

Terrain and soil data and the delineation of landscape units were extracted from a database in

Table 1

Overview on WASA model versions with different complexity of landscape variability and lateral flow redistribution among modelling units

\begin{tabular}{llll}
\hline Model version & $\begin{array}{l}\text { Degree of landscape } \\
\text { variability }\end{array}$ & $\begin{array}{l}\text { Flow redistribution } \\
\text { among terrain } \\
\text { components }\end{array}$ & $\begin{array}{l}\text { Flow redistribution } \\
\text { among soil-vegetation } \\
\text { components }\end{array}$ \\
\hline 1 (reference) & Full & $\mathrm{X}$ & $\mathrm{X}$ \\
2 & $\begin{array}{l}\text { Only dominant } \\
\text { landscape unit }\end{array}$ & $\mathrm{X}$ & $\mathrm{X}$ \\
3 & $\begin{array}{l}\text { Only dominant } \\
\text { soil-vegetation component }\end{array}$ & - & - \\
4 & Mean parameters & - & - \\
5 & Full & - & $\mathrm{X}$ \\
6 & Full & $\mathrm{X}$ & - \\
7 & Full & - & - \\
\hline
\end{tabular}

the SOTER structure set up for the study area by Gaiser et al. (2003b). About 150 landscape units were differentiated and about 50 different soil types or subtypes were recorded for the soil-vegetation components throughout the study area. Each was represented in the data base by at least one representative profile with horizon specific soil based on a small number of measured data for vegetation types of the study area and from studies in other semi-arid environments. Details on the estimation of terrain, soil and vegetation parameters for WASA are given in Appendix C.

\subsection{Model versions}

The reference version of WASA (Model 1) comprises the full range of landscape variability, process representation and available data as described in the previous sections The hierarchy of spatial modelling units starts out from a sub-division of Ceará into 107 catchments of about $1500 \mathrm{~km}^{2}$ in size. Each is made up of several grid cells of 10 by $10 \mathrm{~km}$ as defined by the resolution of the precipitation data set (Chapter 3.2). Model 1 was considered to be the conceptually best model version in view of the given data availability and the perception of the hydrological behaviour of the study area.

Several other model versions with a reduced complexity in terms of landscape variability and flow redistribution were tested (Table 1 for an overview). In Model 2, only the landscape unit with the largest areal fraction in each grid cell was considered while properties. Vegetation parameters were estimated 
disregarding all smaller landscape units. All other landscape heterogeneities at smaller scale levels within the chosen landscape unit were retained with the same detail as in Model 1. In Model 3, the parameters of the dominant soil-vegetation component were assigned to the entire cell. Model 4 used mean terrain, soil and vegetation parameters within each grid cell, derived as area-weighted mean of the full variability considered in Model 1. Models 5-7 consider to a different degree the runoff redistribution processes among the modelling units. In Model 7, the runoff from a grid cell is simply the sum of the contributions of all individual sub-areas, without any flow redistribution among terrain components or soil-vegetation components.

The simulation was executed for all model versions for the period 1960-1998 with a daily time-step. A subset of 10 particularly dry years comprised the following years (in order of decreasing annual area-average rainfall for Ceará with 10-year mean of $610 \mathrm{~mm}):$ 1980, 1981, 1979, 1992, 1990, 1966, 1970, 1998, 1983, and 1993. The subset of the 10 wettest years (in order of increasing rainfall with 10-year mean of $1370 \mathrm{~mm}$ ) was: 1975, 1971, 1989, 1961, 1986, 1973, 1963, 1964, 1985, and 1974.

In simple sensitivity experiments with Model 1, parameter values were increased and decreased by previously fixed ratios relative to the best-guess values in the original Model 1 . The change ratios were chosen according to an assumed range of parameter uncertainty, depending on the detail and accuracy of the available data.

\section{Results of model applications}

1009

\subsection{General model validation 1011}

1012

The reference version of WASA (Model 1) was applied to the entire study area of Ceará without calibration Simulated mean annual river discharge was generally of the right order of magnitude compared to the observed values for catchments of different sizes No systematic over- or underestimation was found when looking at the entire set of available stations (Fig. 5a). However, the performance varied considerably between the gauging stations, with very good (deviation of mean annual runoff $<5 \%$ ) to poor (deviation $>20 \%$ ) results according to an interpretation of quantitative performance criteria for large dryland basins (Andersen et al., 2001). It is pointed out that where runoff is only a small fraction of rainfall, small deviations in any input parameter may result in a large percentage deviation of simulated runoff. For instance, percentage deviations in annual precipitation cause percentage changes in annual runoff estimates to be larger by a factor of 2-3 (Güntner and Bronstert, 2003). This is in line with results for other semi-arid areas, e.g. by Arnell (2000). Errors in rainfall, which is the most uncertain input variable in view of the low station density, may thus cause the large deviations in simulated runoff, amplified by various other sources of uncertainty. Model performance was generally better for larger catchments where such uncertainties average out to some extent (Fig. 5), although the value of this result is (b) Coefficient of variation (a) Mean annual discharge

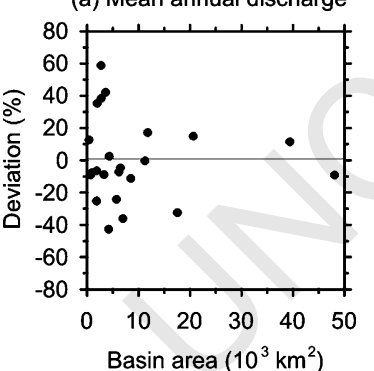

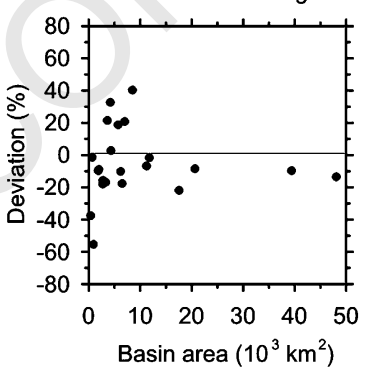

of annual discharge (c) Mean monthly discharge

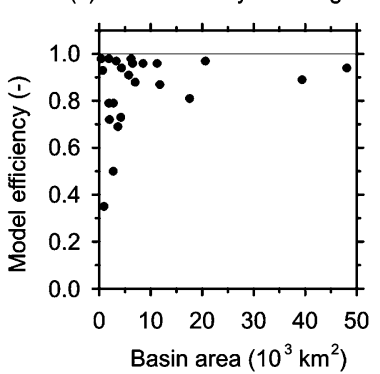

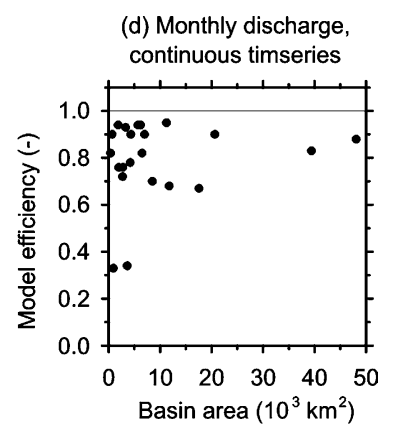

1044

1045

1046

1047

1048

1049

1050

1051

1052

1053

1054

1055 1056 


\section{ARTICLE IN PRESS}

A. Güntner, A. Bronstert / Journal of Hydrology $x x$ (0000) xxx-xxx

(a) Iguatu, $19300 \mathrm{~km}^{2}$

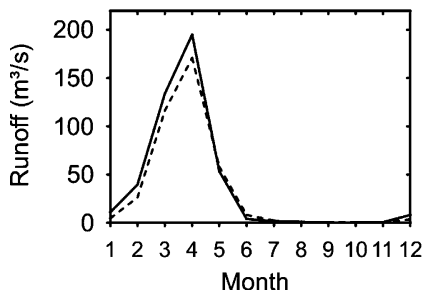

(b) Icó, $11900 \mathrm{~km}^{2}$

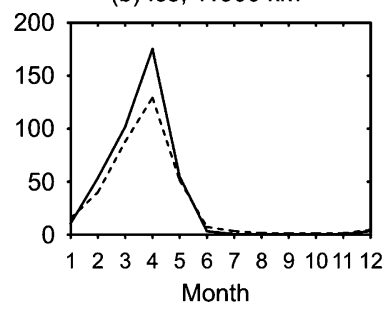

(c) Peixe Gordo, $47300 \mathrm{~km}^{2}$

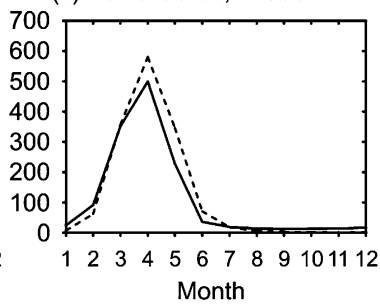

(d) Croatá, 1050 km²

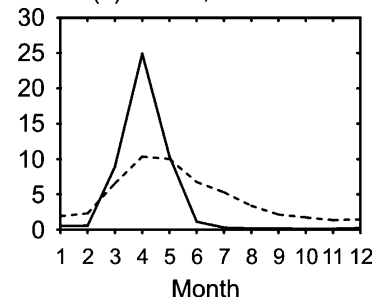

1105

1106

1107

1108

1109

1110

1111

1112

1113

1114

1115

1116

1117

1118

1119

1120

1121

1122

1123

1124

1125

1126

1127

1128

1129

1130

1131

1132

1133

1134

1135

1136

1137

1138

1139

1140

1141

1142

1143

1144

1145

1146

1147

1148

1149

1150

1151

1152 


\subsection{Sensitivity to the spatial model structure}

At the scale of grid cells $\left(100 \mathrm{~km}^{2}\right)$, differences in simulated mean annual runoff between models of different detail of the landscape data (comparing Model 1 and 2, using several or only one landscape unit per grid cell, respectively) were in the range of $\pm 40 \%$ (Fig. 8a). Thus, for the given type and resolution of data on landscape characteristics, differences in the hydrological response of adjacent landscape units can be large. Taking into account these differences by using several landscape units, may therefore be of importance for runoff assessment at scales similar to that of the grid cells. On the other hand, the mean and median of the differences for all cells of the study area were close to zero (Fig. 8a, Table 2). Thus, for the aggregate response at the scale of the entire study area (about $10^{5} \mathrm{~km}^{2}$ ), the loss of detail of landscape information in Model 2 did not result in a significant worsening of the simulation results. The sub-division of the study area into grid cells of $100 \mathrm{~km}^{2}$ captured major spatial variability at the scale of landscape units with sufficient detail. Note, however, that although only one landscape unit was used in each grid cell in Model 2,

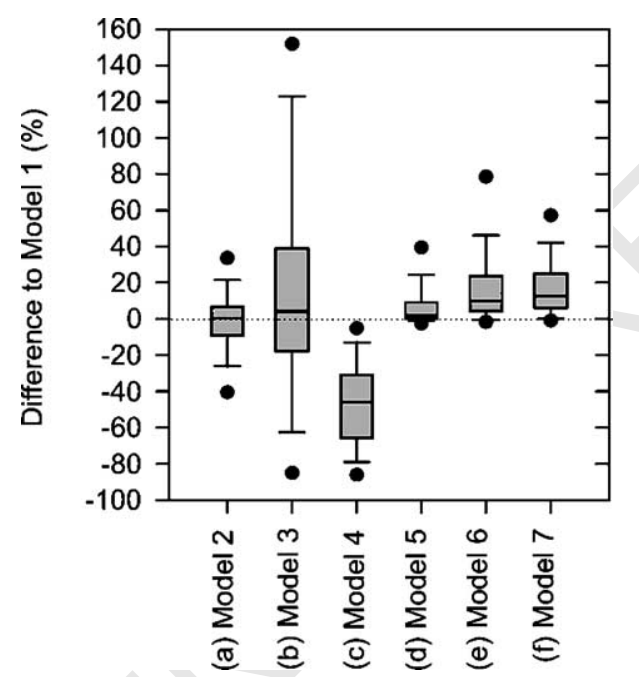

Fig. 8. Box-whisker plots of the percentage differences in simulated mean annual runoff for several WASA model versions relative to the reference Model 1. Distribution of differences for the 1460 grid cells $\left(10 \times 10 \mathrm{~km}^{2}\right)$ in the study area of Ceará. Boxes are limited by the 25th and 75th percentile, whiskers mark 10th and 90th percentile, dots mark 5 th and 95 th percentile.
Table 2

1201

Mean annual values of components of the hydrological cycle 1202 (Period 1960-1998) for several WASA model versions

\begin{tabular}{|c|c|c|c|c|c|c|c|c|}
\hline & & $Q$ & $\mathrm{CV}$ & $Q_{\text {hort }}$ & $Q_{\text {lat }}$ & $E$ & $Q_{\text {wet }}$ & $Q_{\text {dry }}$ \\
\hline Model 1 & & 148 & 1.14 & 64 & 41 & 694 & 303 & 41 \\
\hline \multirow[t]{2}{*}{ Model 2} & $(\mathrm{~mm})$ & 147 & 1.17 & 64 & 42 & 695 & 300 & 41 \\
\hline & $\Delta(\%)$ & -1 & 3 & 0 & 2 & 0 & -1 & 0 \\
\hline \multirow[t]{2}{*}{ Model 3} & $(\mathrm{~mm})$ & 170 & 1.24 & 87 & 39 & 678 & 322 & 60 \\
\hline & $\Delta(\%)$ & 15 & 9 & 36 & -5 & -2 & 6 & 46 \\
\hline \multirow[t]{2}{*}{ Model 4} & $(\mathrm{~mm})$ & 85 & 1.97 & 0 & 40 & 755 & 206 & 11 \\
\hline & $\Delta(\%)$ & -43 & 73 & -100 & -2 & 9 & -32 & -73 \\
\hline \multirow[t]{2}{*}{ Model 5} & $(\mathrm{~mm})$ & 152 & 1.09 & 62 & 49 & 690 & 304 & 45 \\
\hline & $\Delta(\%)$ & 3 & -4 & -3 & 20 & -1 & 0 & 10 \\
\hline \multirow[t]{2}{*}{ Model 6} & $(\mathrm{~mm})$ & 162 & 1.01 & 60 & 46 & 681 & 315 & 55 \\
\hline & $\Delta(\%)$ & 9 & -11 & -6 & 12 & -2 & 4 & 34 \\
\hline \multirow[t]{2}{*}{ Model 7} & $(\mathrm{~mm})$ & 169 & 0.96 & 59 & 53 & 675 & 322 & 59 \\
\hline & $\Delta(\%)$ & 14 & -16 & -8 & 29 & -3 & 6 & 44 \\
\hline
\end{tabular}

Average values for the study area Ceará; $\Delta$ : percentage 1217 differences relative to the reference Model $1 ; Q$ : mean annual 1218 total runoff; CV: Coefficient of variation of annual discharge; $Q_{\text {hort }}: 1219$ mean annual Horton-type infiltration excess-runoff; $Q_{\text {lat }}$ : mean 1220 annual lateral subsurface flow; $E$ : actual evapotranspiration; $Q_{\text {wet }}$ : 1221 runoff in subset of 10 wettest years; $Q_{\mathrm{dry}}$ : runoff in subset of 10 wettest years.

sub-scale variability was considered by terrain and soil-vegetation components.

In Model 3, all sub-scale variability was excluded by assigning only the dominant soil-vegetation component to each grid cell. The estimated differences in mean annual runoff at a cell basis compared to the reference Model 1 were negative or positive with a large scatter between cells (Fig. 8b), and estimated mean annual runoff for the whole area was about $15 \%$ larger in Model 3 (Table 2). One reason for the increase was that the dominant soil-vegetation components in grid cells, which were now attributed to the entire grid cell, are often areas with rather shallow or clayey soils occurring in slope positions and producing comparatively large runoff volumes. Smaller units with large storage capacities were skipped in Model 3. This applies, for instance, for deeper alluvial soils in valley bottoms which had an areal fraction on the total study area of $3 \%$ in Model 1. In addition, using only one modelling unit in grid cells in Model 3 eliminated redistribution processes between modelling units which tended to reduce total runoff in Model 1 (see below).

Using no sub-scale variability and only one modelling unit with mean parameters in each grid 


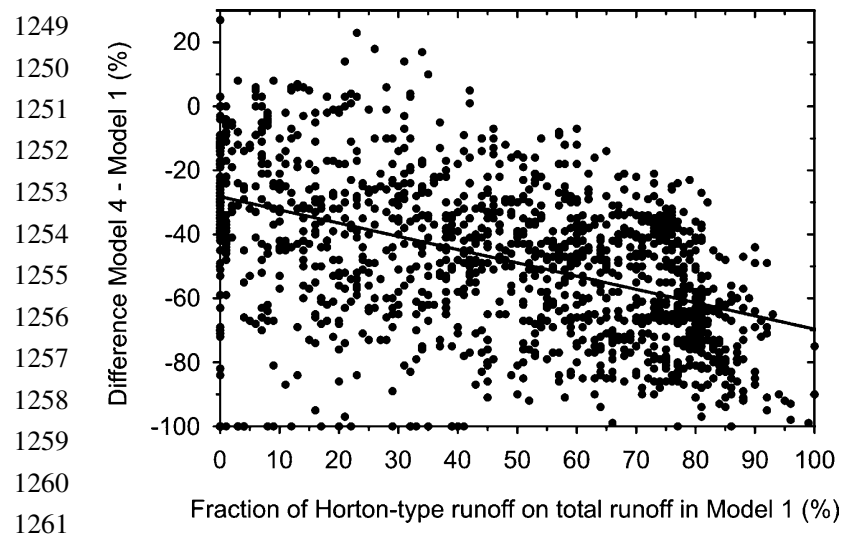

Fig. 9. Difference in simulated mean annual runoff between Model 4 without landscape variability within grid cells and the reference Model 1, as a function of the fraction of Horton-type infiltrationexcess runoff for the 1460 grid cells in Ceará.

cell (Model 4) gave estimates of mean annual runoff consistently smaller than for the reference Model 1 for all grid cells (Fig. 8c). Averaged over the entire study area, the reduction was large, at about $-43 \%$ (Table 2). For cells with a larger proportion of Horton-type infiltration-excess runoff the effect of using mean parameters tended to produce more pronounced reductions (Fig. 9). This difference between both model versions was mainly a consequence of the strong non-linearity of the infiltration process, where with spatially averaged soil parameters rainfall intensities rarely exceed the hydraulic conductivity of the soil. The volume of infiltrationexcess runoff declined to zero while the additionally infiltrating water was almost completely consumed by evapotranspiration (Table 2). The results correspond to those obtained in other studies where inappropriate mean parameter values have been used (Merz and Plate, 1997).

\subsection{Sensitivity to lateral redistribution processes}

Model versions 5-7 with a reduced representation of lateral interaction of water fluxes between the modelling units at different scales resulted in larger simulated runoff than the reference model (Table 2) If total runoff was simply the sum of runoff volumes from all individual sub-areas (Model 7), mean annual runoff was $14 \%$ larger at the aggregate scale of Ceará, and in parts more than $40 \%$ for individual cells
(Fig. 8f). Due to a variety of interacting factors it is difficult to work out clearly the conditions which favour this effect of lateral redistribution. The main relevant process is re-infiltration of surface runoff flowing as runon into adjacent areas in the landscape (soil-vegetation components and terrain components in the model structure of WASA) with higher infiltration capacity. The example in Fig. 10 illustrates that the absolute effect of redistribution, expressed by a large increase in the difference of soil moisture between Models 1 and 7, is often most pronounced shortly after the onset of the rainy season. At that time, soil moisture in a patch acting as a source area of surface runoff (the terrain component of higher topographic position in Fig. 10) is already large enough to generate a substantial amount of runoff while at the same time soil moisture in another unit is still low enough to act as sink area (the lower terrain component in Fig. 10).

The results show a tendency for the relative effect of lateral redistribution to be more pronounced in areas with lower runoff volumes in absolute terms (Fig. 11a). In these cases, the average drier soil conditions due to lower rainfall volumes or more permeable soils provide more storage capacity for re-infiltration. The redistribution effect also can be expected to be larger in areas with soils with strongly differing water retention characteristics close to each other which contrast markedly in their behaviour as runoff source or sink areas. A clear relationship between the magnitude of the redistribution effect and the areal fraction of soils with particularly high infiltration and storage capacity such as alluvial soils, however, could not be demonstrated (Fig. 11b). Furthermore, the effect of taking into account lateral redistribution of water fluxes was found to be of considerable importance in areas with a significant generation of lateral subsurface flow, i.e. in landscape units with steep topography (Fig. 11c). In the reference Model 1, the subsurface flow component generated in an upslope area increased soil moisture in the terrain component with the lowest topographic position such as the valley bottoms, and was to a large part extracted by evapotranspiration. In Model 7, however, it contributed directly to total runoff without any losses.

Considering Models 5 and 6, random variability of landscape characteristics within hillslope segments 

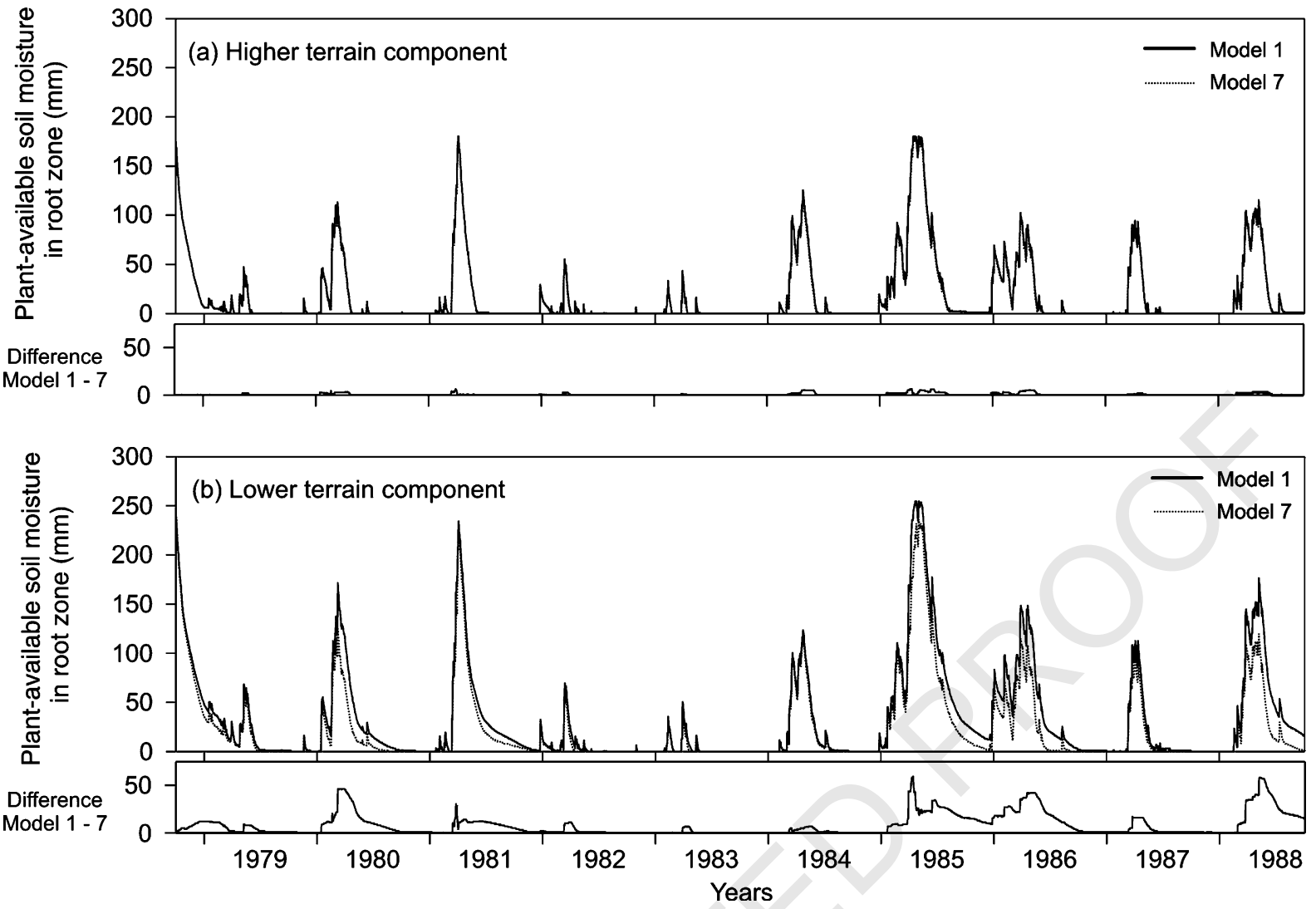

Fig. 10. Plant-available soil moisture in the root zone of two adjacent terrain components of different topographic position in a small sub-basin $\left(200 \mathrm{~km}^{2}\right)$ in Ceará, simulations with Model 1 and 7 , and differences in soil moisture between both models.

(Model 5 with interaction between soil-vegetation components) was found to have a larger relative effect on total runoff reduction at the basin scale by redistribution among modelling units than organised
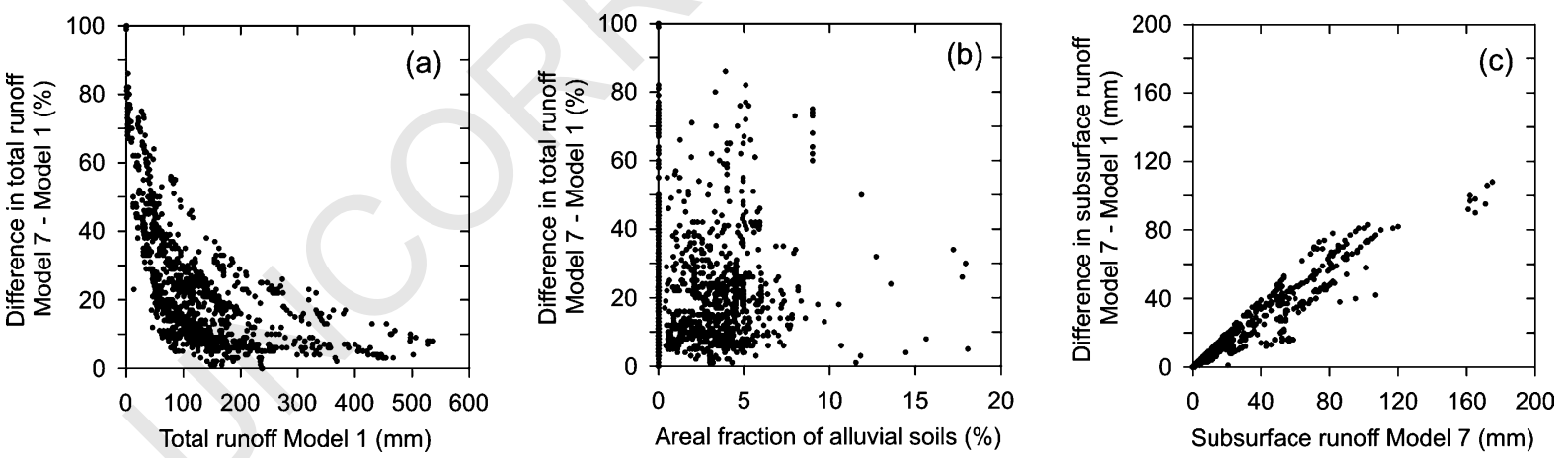
variability along toposequences (Model 6 with interaction between terrain components) (Table 2, Fig. 8d and e). This larger relative importance of random variability may, on the one hand, be

1422

1423

Fig. 11. Effect of disregarding lateral redistribution of water fluxes among modelling units in WASA for the $10 \times 10 \mathrm{~km}^{2}$ grid cells in Ceará in 1438 Model 7 relative to the reference Model 1, in terms of (a) mean annual runoff, (b) the areal fraction of alluvial soils in grid cells, and 1439 (c) subsurface flow components. 
reasonable in view of observations in many semi-arid environments which favour runoff-runon processes over small distances (Section 1). Also Bronstert and Bárdossy (1999) found a stronger impact of random as compared to organised soil moisture variability on runoff, although for different scales and environmental conditions. On the other hand, one may argue that the contribution of random variability is overestimated in the WASA application because too much landscape variability has been attributed to random variability when parameterizing the model. A reason is the low spatial resolution of the given terrain, soil and land use data, which does not allow recognition of all the patterns of organization that may exist in the landscape. As a consequence, the information on soil and land use heterogeneity is used to define various soil-vegetation-components without being able to arrange them within a toposequence structure. More detailed spatial data might have allowed a better understanding of additional characteristic toposequences which would increase the importance of structured variability at the expense of random variability. The net effect of both types of interacting variability on total runoff at the catchment scale may nevertheless be similar to Model 1, which should be analysed for an areas where more detailed spatial data were available.

The relative effect of lateral redistribution of fluxes between modelling units on total runoff was more apparent in dry years as compared to wet years, with differences in mean annual runoff between Models 1 and 7 of 44 and $8 \%$ for both sets of years, respectively (Table 2). In dry years, the refillable soil moisture storage in units adjacent to those generating runoff is expected to be larger in average. Therefore, a larger fraction of generated runoff in soil-vegetationcomponents and terrain components is retained and consumed by evapotranspiration. Additionally, the relative effect is larger because absolute flow volumes are smaller than in wet years. Lateral redistribution processes including re-infiltration can thus substantially contribute to the non-linear hydrological response between wet and dry conditions in this type of environment. Similarly, Goodrich et al. (1997) showed an increasingly non-linear response with increasing catchment area due to, among others, the effect of transmission losses in semi-arid basins. As a consequence of differences between wet and dry years, the inclusion of lateral redistribution processes in Model 1 also increased the interannual variability of total runoff at the scale of grid cells (see coefficients of variation in Table 2). The fact that the simulated interannual variability of discharge in Model 1 was close to the observed variability (see Fig. 5c and discussion above) corroborated the need to take into account the interaction between the modelling units.

These results for model sensitivity to lateral redistribution processes may have important consequences for model applications in the context of environmental change impact assessment. The simulated magnitude of change in discharge for any change in precipitation in a climate scenario will be influenced by lateral redistribution effects. For example, assuming a decreasing precipitation trend and keeping all other factors constant, the decreasing trend for discharge will be underestimated by the model if lateral redistribution processes are not taken into account.

\subsection{Parameter sensitivity for dry and wet conditions}

As a consequence of the highly variable semi-arid climate, the sensitivity of model parameters on runoff simulations was also found to be of different magnitudes for wet and dry climatic boundary conditions. Bedrock parameters such as the soil depth to bedrock, for instance, were more sensitive in wet years (Fig. 12a). Only in these wet conditions, percolation through the soil profile penetrates deep enough to be influenced by the bedrock characteristics. For soil parameters such as hydraulic conductivity or porosity, in contrary, the model reacted more sensitively in dry years where infiltration-excess runoff generation and, consequently, the near-surface characteristics dominate the runoff response (Fig. 12b and c). Note, however, that in the case of soil hydraulic conductivity there are hardly any changes in average runoff if this parameter is set to larger values than in the original model. Also differences in sensitivity between wet and dry years are small in that case. The reason is that a reduction in simulated infiltration-excess runoff due to a larger hydraulic conductivity is compensated by an increase in lateral subsurface flow (Table 3). For vegetation parameters, a larger model sensitivity for simulated runoff was generally found in wet years (Fig. 12d-f). In these years, usually 
(a) Depth to bedrock

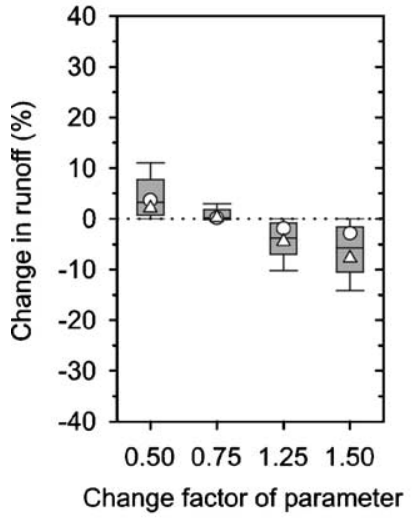

(d) Canopy height

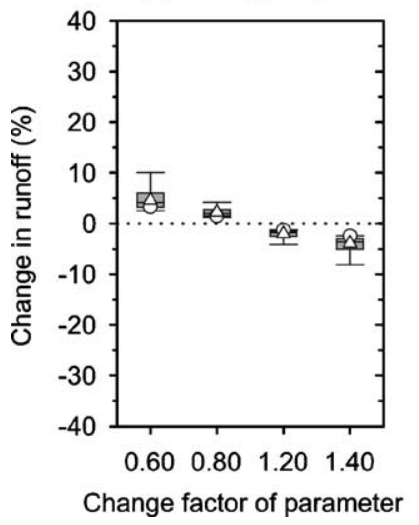

(b) Soil conductivity

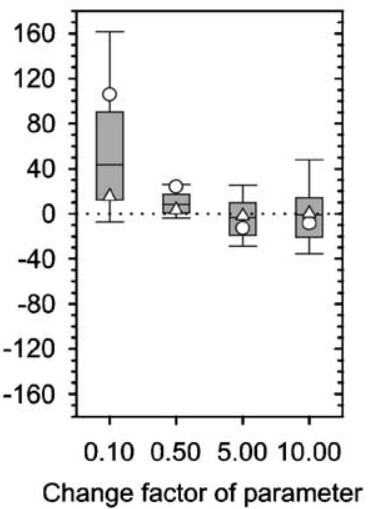

(e) Root depth

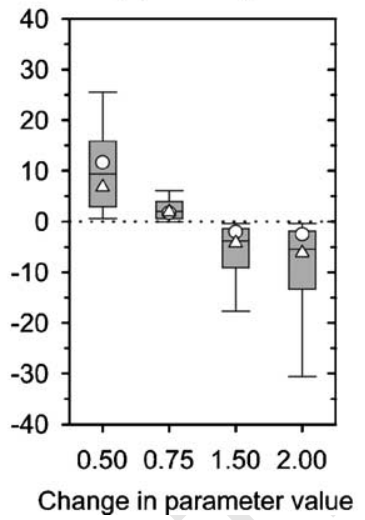

(c) Soil porosity

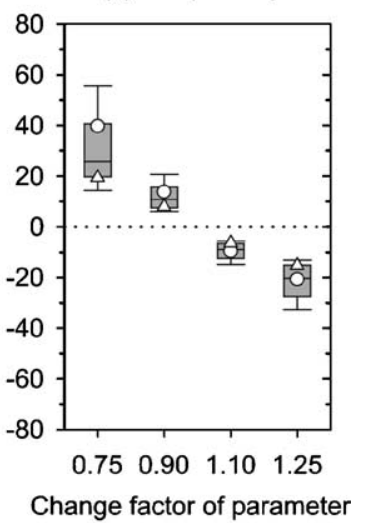

(f) Minimum stomata

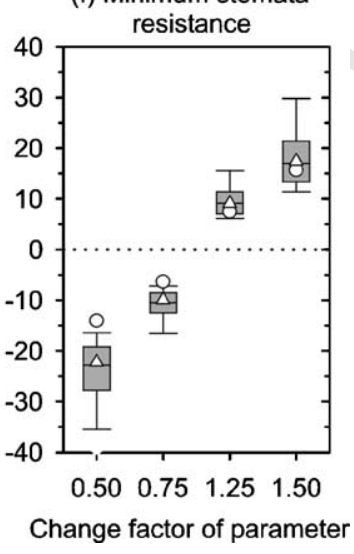

1585

1586

1587

1588

1589

1590

1591

1592

1593

1594

1595

1596

1597

1598

1599

1600

1601

1602

1603

1604

1605

1606

1607

1608

1609

1610

1611

1612

1613

1614

1615

1616

1617

1618

1619

1620

1621

1622

1623

1624

1625

1626

1627

1628

1629

1630

1631

1632 
this is also of importance for scenario simulations where simulated runoff trends for climate change scenarios differ in reliability for a decreasing or an increasing precipitation trend.

\section{Summary and conclusions}

\subsection{The landscape discretization scheme}

The hierarchical multi-scale concept for structuring the landscape into modelling units in the WASA model provides a way to represent dominant hydrological processes of semi-arid environments at their specific scales while linking these process scales with the final scale of interest of model application, i.e. large catchments. Besides taking into account the heterogeneity of the landscape and of related vertical processes, the modelling units are also defined with regard to lateral processes, in particular the redistribution of water fluxes between patches at the hillslope or small-basin scale. Accordingly, landscape units are delineated which are characterized by similarity in sub-scale variability, including both random and structured variability. In order to define organisation in landscape features, a toposequence approach is used. It assigns soil, vegetation and land use patches to zones of a specific topographic position within the landscape which allows to define runoff-runon relationships between the modelling units. Thus, features of the landscape structure of importance for lateral redistribution processes are respected a priori in the spatial discretization scheme. This overcomes the frequent problem in (semi-)distributed models of defining the lateral connectivity between the modelling units that have been delineated according to the similarity of vertical processes only.

\subsection{Assumptions and limitations of the concept}

Starting with the terrain components and going to finer scales in WASA, areal fractions of modelling units and their location relative to each other instead of their geographically explicit locations are used. On the one hand, it is a simplification to use the areal fraction as the only parameter which determines the portions of runoff volumes that are re-distributed as runon among other modelling units, and the validity of this model assumption could not be directly checked in this study due to the lack of adequate small-basin scale observations. On the other hand, the use of areal fractions is an efficient approach to capture aspects of landscape variability and patch interaction in large-scale applications due to limited data availability (where the best available information in many cases is the areal fraction only) and due to the necessity to limit computation times. However, there are important aspects of landscape variability and lateral redistribution effects that go beyond the approach used here. Beneath the finest-scale units in the WASA hierarchy, plot variability at the scale of few meters (e.g. crusted/non-crusted soils, microtopography, or random variability of soil hydraulic conductivity) is not captured in the model. Beyond the coarsest-scale of the WASA hierarchy, regional groundwater flow is disregarded. Although the importance of plot-scale variability on the hydrological response has been shown in a large number of studies, its significance may decline relative to the other aspects of variability at larger scales which are described in the current approach. Testing this hypothesis should be the subject of future work. At coarser spatial scales, an extension of the function of landscape units as source or sink areas for regional, long-distance groundwater fluxes may be a straightforward extension of the WASA structure for study areas where such fluxes are considered to be of importance.

\subsection{Implications for representing spatial} heterogeneity in large-scale models

According to the simulation results, it is concluded that accounting for landscape variability of terrain, soil and vegetation characteristics in the semi-arid environment is important for obtaining reasonable annual and monthly discharge simulations at the scale of large river basins $\left(10^{4}-10^{5} \mathrm{~km}^{2}\right)$. Specifying one landscape unit, i.e. one specific form of sub-scale variability, for a $100 \mathrm{~km}^{2}$ grid cell was found to be an adequate complexity to estimate the large-scale hydrological response. Disregarding the sub-grid variability is not advisable in two respects: First, using mean parameter values led to a considerable underestimation of runoff volumes, 
particularly in areas where the Horton-type infiltration-excess runoff process prevails. Second, using only the dominant soil-vegetation type led to an overestimation of runoff at the large scale because sub-areas with small areal fractions acting as runoff sink areas were omitted.

Implications for representing lateral water redistribution in large-scale models. The simulation results demonstrate that lateral water fluxes and related redistribution processes at the hillslope or small-basin scale can considerably influence the hydrological response at the scale of river basins in the semi-arid environment. The main effect is a reduction of runoff volumes at larger scales due to re-infiltration of surface runoff and redistribution of subsurface runoff. Soil moisture patterns in the landscape are thus in part under non-local control, particularly for wet conditions. The effect was found to be more important in areas with lower runoff volumes and with steeper slope gradients. It is concluded that the runoff response of large catchments cannot simply be represented as the sum of the contributions of individual sub-areas, but lateral interaction between them due to landscape variability has to be taken into account also in large-scale models. In this sense, the results indicate that even a (soil moisture) distribution-based approach, although fulfilling the need to represent sub-scale landscape variability, may not be adequate as long as it does not account for redistribution effects which, e.g. may contribute to changes in the shape of the distribution in time.

\subsection{Sensitivity for wet and dry conditions}

The relative effect of lateral redistribution processes on total basin discharge was found to be more pronounced in dry years as compared to wet years. The high amplification factor that relates changes in annual rainfall to larger percentage changes in annual runoff in semi-arid areas can therefore be at least partly attributed to the redistribution processes. Thus, they have to be taken into account in process-based hydrological models if the magnitude of change in runoff in the context of climate change and related precipitation change is to be adequately assessed. Additionally, model sensitivity to uncertainties in model parameter values differs between years with rainfall volumes being above or below the average due to a changing relevance of individual processes. Thus, for model applications in the context of climate change impact assessment, the uncertainty of a simulated long-term change in discharge due to uncertainties originating from individual process representations and model parameters varies between scenarios with increasing or decreasing precipitation trends. For model uncertainty assessments in this regard we conclude that there is a need to pursue a process-based approach, i.e. the analysis of uncertainty from different sources as a function of changing boundary conditions and, consequently, a changing dominance of individual hydrological processes.

\subsection{Transferability of the concept}

The approach for landscape discretization developed in this study is in principle considered to be well transferable to large-scale applications in other areas, including its applicability as sub-grid parameterization of the land surface in climate models. Also in more humid areas, a hierarchical way of structuring the landscape and landscape variability which comprises a sub-division into a small number of (two or three) topographic zones including their topological relationships may be suitable to describe the effect of natural heterogeneity for the coarse-scale hydrological response in a manageable way. A practical constraint for a transfer of the approach to other areas, however, will usually be the lack of data in a structure similar to SOTER, which includes direct relationships between topographic, soil and vegetation characteristics. Assembling such multidisciplinary data sets for large areas and testing their applicability to adequate landscape discretization for hydrological and other ecosystem models is a challenge for future research on improving coarse-scale models.

\section{Acknowledgements}

The authors acknowledge funding of this work by the German Ministry for Education and Research $(\mathrm{BMBF})$ within the Brazilian-German research 
programme WAVES. Similarly, we acknowledge the complementary funding by the Brazilian Conselho Nacional de Desenvolvimiento Científico e Tecnológico (CNPq) which supported co-operation. We gratefully acknowledge provision of hydrometeorological data for this study by Brazilian institutions, in particular SUDENE and COGERH in Fortaleza, Brazil. The Global Runoff Data Centre (GRDC, D-56002 Koblenz, Germany) provided part of the discharge data used in this study. The reviewers H. Gupta and M.J. Kirkby are thanked for their helpful suggestions to improve the text.

\section{Appendix A. Details of process representation in WASA}

Interception by the vegetation cover is modelled in WASA by a simple bucket approach with the interception capacity being a function of the leaf area index (Dickinson, 1984). Evapotranspiration is simulated with the approach for a sparse vegetation cover by Shuttleworth and Wallace (1985), which also accounts for evaporation from bare soil surfaces. An increase in canopy surface resistance to transpiration due to environmental stress factors such as low soil water availability is respected according to Jarvis (1976) and Stewart (1988).

The infiltration model is a Green-Ampt approach in a formulation given by Schulla (1997), extended in WASA for the infiltration into layered soils. The total input to the infiltration routine is rainfall minus interception plus surface runoff from other spatial units. A temporal scaling factor is applied when modelling with daily temporal resolution in order to compensate for underestimated rainfall intensities (Güntner, 2002).

Percolation from one horizon to the next deeper horizon occurs if the actual moisture SM of the upper horizon exceeds soil moisture at field capacity $\mathrm{SM}_{\mathrm{FC}}$. Following Arnold et al. (1990), a temporal delay factor $t_{\mathrm{d}}$ in percolation (or travel time through the horizon) is applied which is related to the actual unsaturated hydraulic conductivity $k_{\mathrm{u}}$ of the horizon
(Eqs. (A1) and (A2)).

$\mathrm{PERC}=\left(\mathrm{SM}-\mathrm{SM}_{\mathrm{FC}}\right)\left(1-\exp \left(-\frac{1}{t_{\mathrm{d}}}\right)\right)$

$t_{\mathrm{d}}=\frac{\left(\mathrm{SM}-\mathrm{SM}_{\mathrm{FC}}\right)}{k_{\mathrm{u}}}$

The final volume of PERC may be constrained by the refillable porosity of the lower horizon or by its saturated hydraulic conductivity $k_{\mathrm{s}}$. If the lowest horizon of the profile is situated above bedrock, percolation to deep groundwater may be limited by the hydraulic conductivity of the bedrock.

For the quantification of lateral subsurface flow LATF leaving a soil horizon, a simple relationship for saturated flow based on the Darcy equation is applied (Eq. (A3)). Comparable formulations for more complex geometric settings have been used by Wigmosta et al. (1994) and Tague and Band (2001). The hydraulic gradient is given by the slope gradient $s_{\mathrm{TC}}$ of the terrain component. Fig. A1 illustrates the geometric attributes to quantify the effective cross section $A_{\mathrm{Q}}$ for lateral flow, which can be determined following Eq. (A4). The saturated depth $d_{\mathrm{s}}$ of the contributing horizon is assumed to build up on its lower boundary, with $d_{\mathrm{s}}$ being a function of the total depth $d$ of the horizon and of the actual moisture content relative to saturated water content $\mathrm{SM}_{\text {sat }}$ (Eq. (A5)).

$\mathrm{LATF}=A_{\mathrm{Q}} k_{\mathrm{S}} s_{\mathrm{TC}}$

$A_{\mathrm{Q}}=2 l_{\mathrm{SVC}} d_{\mathrm{s}}=2 \frac{0.5 A_{\mathrm{SVC}}}{a_{\mathrm{TC}} l_{\mathrm{LU}}} d_{\mathrm{s}}=\frac{a_{\mathrm{SVC}} a_{\mathrm{TC}} A_{\mathrm{LU}}}{a_{\mathrm{TC}} l_{\mathrm{LU}}}$

$$
=\frac{a_{\mathrm{SVC}} A_{\mathrm{LU}}}{l_{\mathrm{LU}}} d_{\mathrm{s}}
$$

$d_{\mathrm{s}}=d \frac{\mathrm{SM}-\mathrm{SM}_{\mathrm{FC}}}{\mathrm{SM}_{\mathrm{sat}}-\mathrm{SM}_{\mathrm{FC}}}$

In Eq. (A4), $l_{\mathrm{SVC}}$ is the contour length of the SVC parallel to a downslope TC or to river, $l_{\mathrm{LU}}$ is the slope length of landscape unit, $A_{\mathrm{SVC}}$ is the area of the soil-vegetation component, $A_{\mathrm{LU}}$ is the area of landscape unit, $a_{\mathrm{TC}}$ is the areal fraction of TC in the landscape unit, and $a_{\mathrm{SVC}}$ is the areal fraction of the SVC in the terrain component (see also Fig. A1). The factor 2 in the first term of Eq. (A4) is introduced 


\section{ARTICLE NN PRESS}

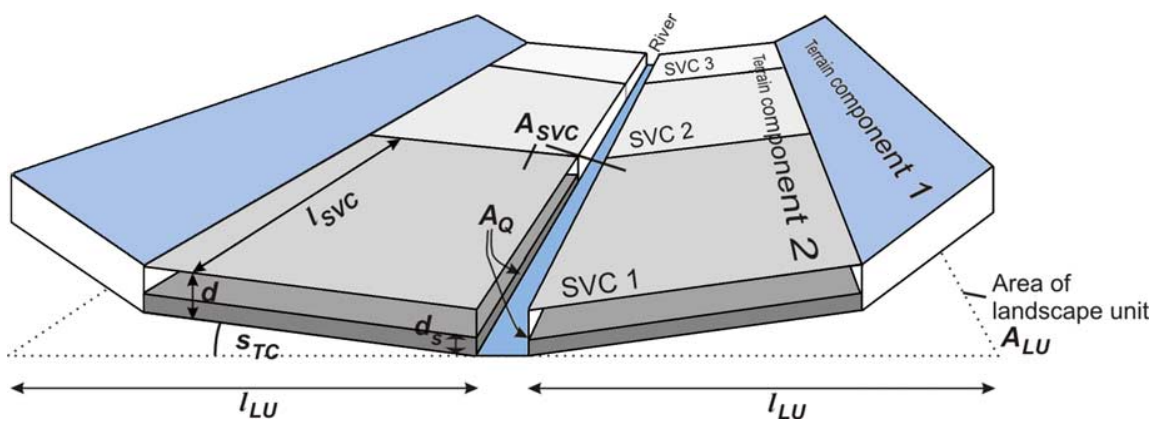

Fig. A1. Scheme of the structure of terrain components (TCs) and soil-vegetation components (SVCs) within a landscape unit (LU), with geometric attributes to calculate lateral subsurface flow (Eq. (A3)-(A5)), here for SCV1 as an example. For simplicity of painting, the soil profile of SVC1 is composed of one horizon only.

because the spatial units with their cross sections for lateral flow are assumed to occur on the hillslopes along both sides of the river.

The total outflow $Q$ from a horizon (Eq. (A6)), being the sum of the independently determined components PERC and LATF, must not exceed the available soil moisture above field capacity in the horizon. Otherwise, both flow components are linearly reduced to their final flow volumes $P_{E R C_{\text {fin }}}$ and $\mathrm{LATF}_{\text {fin }}$ according to Eq. (A7).

$Q=\mathrm{PERC}+\mathrm{LAT}$

if $Q>\left(\mathrm{SM}-\mathrm{SM}_{\mathrm{FC}}\right)$ then

$$
\left\{\begin{array}{l}
\mathrm{PERC}_{\mathrm{fin}}=\left(\mathrm{SM}-\mathrm{SM}_{\mathrm{FC}}\right) \frac{\mathrm{PERC}}{Q} \\
\mathrm{LATF}_{\mathrm{fin}}=\left(\mathrm{SM}-\mathrm{SM}_{\mathrm{FC}}\right) \frac{\mathrm{LATF}}{Q}
\end{array}\right.
$$

The total lateral subsurface outflow of a profile is the sum of the individual flows from each horizon. It is redistributed among profiles in other SVCs or TCs and river flow according to the descriptions in Chapters 2.4 and 2.5 .

\section{Appendix B. Temporal sequence of process modelling}

The temporal sequence of process modelling within each time-step in WASA, including lateral redistribution among modelling units as explained in Chapters 2.4 and 2.5 , is as follows:
1. Start with the terrain component (TC) of the highest topographic position within the landscape unit (LU) and do the following steps 2-10 for all soil-vegetation components (SVCs) in this terrain component.

2. Update soil moisture of all horizons due to lateral subsurface inflow (produced in the previous timestep) from the upslope TC and from SVCs of the same TC. If the soil water content of a profile exceeds its saturated water content, the surplus lateral inflow becomes surface runoff (return flow).

3. Determine retention of precipitation in the interception storage and calculate interception evaporation.

4. Determine saturation-excess surface runoff by precipitation or lateral surface inflow from upslope TCs (produced in the same time-step) onto the surface-saturated fraction of the SVC (see point 9 below).

5. Calculate infiltration volumes with input from rainfall and lateral surface flow from upslope TCs (produced in the same time-step) and from other SVCs of the same TC. In order to account in an approximate manner for surface runoff that may be produced simultaneously on other SVCs, the infiltration routine is applied with two iterations. As a first estimation, infiltration-excess runoff is computed for all SVCs based on input from precipitation and lateral flow from an upper TC only. The resulting surface runoff is then redistributed among all SVCs and accounted for in the second iteration, which calculates 
the final values of infiltration and surface runoff for each SVC.

6. Update soil moisture of all horizons by the infiltrated water volume.

7. Calculate plant transpiration and evaporation from the soil surface (both as function of actual soil moisture) and update the soil moisture of all horizons.

8. Calculate, for each soil horizon, the percolation to the next deeper horizon and determine the lateral subsurface flow volumes to adjacent SVCs and to the next downslope TC or to the river. Update the soil moisture of all horizons according to these outflows.

9. Determine the saturated fraction of the SVC as function of the actual soil moisture content and the distribution of storage capacities.

10. Add up lateral outflow of all SVCs of the current terrain component (surface and subsurface flow, respectively) and distribute among river runoff and inflow to downslope TCs.

11. Repeat steps 2-10 for all SVCs of the next downslope TC.

\section{Appendix C. Details on model parameterization with landscape data}

The delineation of landscape units and the estimation of terrain and soil parameter in WASA was based on a database in the SOTER structure set up for the study area by Gaiser et al. (2003b) using a regional survey at a scale of $1: 10^{6}$ by SUDENE (1972, 1973). Of the about 150 landscape units in the data base, some had very small areas or were very similar to others. No attempt was made to aggregate them in this study as this would have included subjective reasoning in skipping some of the detailed information. An additional attribute was added to the soil and terrain data base to indicate the topographic location of terrain components in the catena of a landscape unit relative to other terrain components. Patterns of natural vegetation types derived from a map at a scale of $1: 10^{6}$ (MDME, 1981a,b), patterns of different forms of agricultural land use available at the scale of administrative units (IBGE, 1998) and data on soil types within the landscape units and terrain components (Gaiser et al., 2003b) were combined to give the distribution of soil-vegetation components in each terrain component throughout the study area (see Güntner, 2002, for details). In this scheme, preferred combinations of land cover and soil types were identified by using suitability indices of the different soil types for agricultural use (Gaiser et al., 2003b).

The about 50 different soil types or sub-types in the data base of Gaiser et al. (2003b) were each described by at least one representative profile with horizon-specific data on texture, bulk density and content of coarse fragments. Soil porosity (set equal to saturated water content) was estimated from bulk density. Soil water retention characteristics were derived using the model of Van Genuchten (1980), with parameters based on soil texture and the regression equations of Rawls and Brakensiek (1985). Saturated hydraulic conductivity was estimated from porosity with an equation adapted to Brazilian tropical soils by Tomasella and Hodnett (1997). Unsaturated conductivity as a function of water content was again estimated by the relationship of Van Genuchten (1980).

The mean slope lengths of the landscape units were derived from a land surface classification based on radar remote sensing data performed by MDME (1981a,b). Resulting slope lengths in the study area varied between the landscape units from about $200-2500 \mathrm{~m}$. The hydraulic conductivity of the bedrock in the crystalline area was set to $0.1 \mathrm{~mm} \mathrm{~d}^{-1}$, which implies nearly impermeable conditions as often assumed in hydrological studies of the area (Cadier, 1993). If not given by the data of the representative profiles mentioned above, the maximum profile depth to bedrock was set to $1.8 \mathrm{~m}$ in the crystal-line area and to $4.5 \mathrm{~m}$ for alluvial soils in valley bottoms, as estimated from data on the depth of alluvial wells throughout the study area (CPRM, 1999) and data of CPRM (1996) and Manoel Filho (2000).

Vegetation parameters were estimated from measured values of canopy height, biomass, albedo and leaf area index for some vegetation types of the study area given by MDME (1981a,b), Pfister and Malachek (1986); Hayashi (1995), Sampaio et al. (1998), Tiessen et al. (1998) and Halm (2000). Additionally, parameters were taken from a number of studies including values for semi-arid 
environments (Dorman and Sellers, 1989; Dolman, 1993; Schulze et al., 1994; Kelliher et al., 1995; Fennessy and Xue, 1997; Martin, 1998). Vegetation parameters for agricultural crops were based on the crop models EPIC (Williams et al., 1984) and CROPWAT (FAO, 1992). Minimum stomatal resistance was set to $200 \mathrm{~s} \mathrm{~m}^{-1}$ for most vegetation types, corresponding to a value of maximum stomatal conductance of $198 \mathrm{mmol} \mathrm{m}^{-2} \mathrm{~s}^{-1}$ given for semiarid shrubs by Körner (1994). Finally, seven natural vegetation types were differentiated in the study area, together with degraded sub-type for each, and six different classes of the most common agricultural crops. Time-variable vegetation height, root depth, leaf area index and albedo were estimated by an intraannual distribution, as a function of the onset and end of the rainy season (see Güntner, 2002, for details).

\section{References}

Abbott, M.B., Bathurst, J.C., Cunge, A., O'Connell, P.E., Rassmussen, J., 1986. An introduction to the SHE 1: history and philosophy of a physically based, distributed modelling system. Journal of Hydrology 87, 49-59.

Andersen, J., Refsgaard, J.C., Jensen, K.H., 2001. Distributed hydrological modelling of the Senegal River Basin-model construction and validation. Journal of Hydrology 247, $200-214$.

Arnell, N.W., 2000. Thresholds and responses to climate change forcing: the water sector. Climatic Change 46, 305-316.

Arnold, J.G., Williams, J.R., Griggs, A.D., Sammons, N.B., 1990. SWRRB: a basin scale simulation model for soil and water resources management, Texas $\mathrm{A}$ and $\mathrm{M}$ University Press, College Station.

Becker, A., Braun, P., 1999. Disaggregation, aggregation and spatial scaling in hydrological modelling. Journal of Hydrology 217, 239-252.

Becker, A., Nemec, J., 1987. Macroscale hydrological models in support to climate research. In: Solomon, S.I., Beran, M., Hogg, W. (Eds.), The Influence of Climate Change and the Variability on the Hydrologic Regime and Water Resources, IAHS Publication No. 168, pp. 431-445.

Becker, A., Klöcking, B., Lahmer, W., Pfützner, B., 2002. In: Singh, V.P., Frevert, D.K. (Eds.), The hydrological modelling system ARC/EGMO, Mathematical Models of Watershed Hydrology, Water Resources Publications, Littleton/Colorado, pp. 321-384.

Bergkamp, G., 1998. A hierarchical view of the interactions of runoff and infiltration with vegetation and microtopography in semiarid shrublands. Catena 33(3-4), 201-220.

Beven, K., 2002. Runoff generation in semi-arid areas. In: Bull, L.J., Kirkby, M.J. (Eds.), Dryland Rivers-Hydrology and Geomorphology of Semi-arid Channels, Wiley, New York, pp. 57-106.
Beven, K.J., Kirkby, M.J., 1979. A physically based, variable contributing area model of basin hydrology. Hydrological Sciences Bulletin 24(1), 43-70.

Beven, K.J., Calver, A., Morris, E., 1987. The Institute of Hydrology Distributed Model, Institute of Hydrology Report No. 98, 98. Institute of Hydrology, UK.

Birkeland, P.W., 1999. Soils and Geomorphology, Oxford University Press, New York.

Blöschl, G., Sivapalan, M., 1995. Scale issues in hydrological modelling: a review. Hydrological Processes 9, 312-329.

Bonell, M., Williams, J., 1986. The generation and redistribution of overland flow on a massive oxic soil in an eucalyptus woodland within the semi-arid tropics of north Australia. Catena 25, $63-76$.

Boulet, G., Chehbouni, A., Braud, I., Vauclin, M., 1999. Mosaic versus dual source approaches for modelling the surface energy balance of a semi-arid land. Hydrology and Earth System Sciences 3(2), 247-258.

Bromley, J., Brouwer, J., Barker, A.P., Gaze, S.R., Valentin, C., 1997. The role of surface water redistribution in an area of patterned vegetation in a semi-arid environment, south-west Niger. Journal of Hydrology 198, 1-29.

Bronstert, A., 1999. Capabilities and limitations of detailed hillslope hydrological modelling. Hydrological Processes 13(1), 21-48.

Bronstert, A., Bárdossy, A., 1999. The role of spatial variability of soil moisture for modelling surface runoff generation at the small catchment scale. Hydrology and Earth System Sciences 3(4), 505-516.

Bronstert, A., Plate, E.J., 1997. Modelling of runoff generation and soil moisture dynamics for hillslopes and micro-catchments. Journal of Hydrology 198(1-4), 177-195.

Bronstert, A., Güntner, A., Jaeger, A., Krol, M., Krywkow, J., 1999. Großräumige hydrologische Parametrisierung und Modellierung als Teil der integrierten Modellierung. In: Fohrer, N., Döll, P. (Eds.), Modellierung des Wasser- und Stofftrans-ports in großen Einzugsgebieten, Kassel University Press, Kassel, Germany, pp. 31-40, (in German).

Bronstert, A., Jaeger, A., Güntner, A., Hauschild, M., Döll, P., Krol, M., 2000. Integrated modelling of water availability and water use in the semi-arid Northeast of Brazil. Physics and Chemistry of the Earth 25(3), 227-232.

Cadier, E., 1993. Hydrologie des petits bassins du Nordeste brésilien semi-aride-transposition à des bassins non étudiés, ORSTOM, Institut français de recherche scientifique pour le développement en coopération, Collection Études et Thèses Paris, pp. 414.

Cadier, E., Leprun, J.C., Nouvelot, J.F., 1996. Le comportement des bassins versants representatifs du Nordeste Bresilien bilan de la collaboration entre hydrologues et pedologues. In: Chevallier, P., Pouyaud, B. (Eds.), L'hydrologie tropicale: géoscience et outil pour le développement, IAHS Publication No. 238, pp. $41-52$.

Cammeraat, L.H., 2002. A review of two strongly contrasting geomorphological systems within the context of scale. Earth Surface Processes and Landforms 27(11), $1201-1222$. 
Ceballos, A., Schnabel, S., 1998. Hydrological behaviour of a small catchment in the dehesa land use system (Extremadura, SW Spain). Journal of Hydrology 210(1-4), 146-160.

Chamran, F., Gessler, P.E., Chadwick, O.A., 2002. Spatially explicit treatment of soil-water dynamics along a semiarid catena. Soil Science Society of America Journal 66, $1571-1583$.

Chiew, F.H.S., Stewardson, M.J., McMahon, T.A., 1993. Comparison of six rainfall-runoff modelling approaches. Journal of Hydrology 147, 1-36.

CPRM, 1996. Avaliação da potentialidade hídrica e mineral do médio-baixa Jaguaribe. CPRM, Serviço Geológico do Brasil, Fortaleza, Brazil.

CPRM, 1999. Atlas dos recursos hídricos subterrâne-os do Ceará. CPRM, Serviço Geológico do Brasil, Fortaleza, Brazil (CD-ROM).

De Boer, D.H., 1992. Constraints on spatial transference of rainfall-runoff relationships in semiarid basins drained by ephemeral streams. Hydrological Science Journal 37(5), 491-504.

Dickinson, R., 1984. Modeling evapotranspiration for threedimensional global climate models. In: AGU, (Ed.), Climate Processes and Climate Sensitivity, Geophysical Monograph No. 29, 29. American Geophysical Union, pp. $58-72$.

D'Herbes, J.M., Valentin, C., 1997. Land surface conditions of the Niamey region: ecological and hydrological implications. Journal of Hydrology 188-189, 18-42.

Döll, P., Hauschild, M., 2002. Model-based regional assessment of water use: an example for semi-arid Northeastern Brazil. Water International 27, 310-320.

Dolman, A.J., 1993. A multiple-source land-surface energy-balance model for use in general-circulation models. Agricultural and Forest Meteorology 65(1-2), 21-45.

Dorman, J.L., Sellers, P.J., 1989. A global climatology of albedo, roughness length and stomatal resistance for atmospheric general circulation models as represented by the simple biosphere model (SiB). Journal of Applied Meteorology 28, $833-855$.

FAO, 1992. CROPWAT-A computer program for irrigation planning and management, FAO Irrigation and Drainage Paper, No. 46, 46. Food and Agriculture Organization of the United Nations, Rome, Italy.

Fennessy, M.J., Xue, Y., 1997. Impact of USGS vegetation map on GCM simulations over the United States. Ecological Applications 7(1), 22-33.

Fitzjohn, C., Ternan, J.L., Williams, A.G., 1998. Soil moisture variability in a semi-arid gully catchment: implications for runoff and erosion control. Catena 32, 55-70.

Flerchinger, G.N., Cooley, K.R., Hanson, C.L., Seyfried, M.S., 1998. A uniform versus an aggregated water balance of a semi-arid watershed. Hydrological Processes 12(2), 331-342.

Flügel, W.-A., 1995. Delineating hydrological response units by geographical information system analysis for regional hydrological modelling using PRMS/MMS in the drainage basin of the river Bröl/Germany. Hydrological Processes 9(3-4), $423-436$.
Frischkorn, H., Araújo, J.C.de, Santiago, M.M.F., 2003. Water resources of Ceará and Piauí. In: Gaiser, T., Krol, M.S., Frischkorn, H., Araújo, J.C.de (Eds.), Global change and regional impacts: water availability and vulnerability of ecosystems and society in the semi-arid Northeast of Brazil, Springer, Berlin, pp. 87-94.

Gaiser, T., Krol, M.S., Frischkorn, H., Araújo, J.C.de, 2003a. Global change and regional impacts: water availability and vulnerability of ecosystems and society in the semi-arid Northeast of Brazil, Springer, Berlin.

Gaiser, T., Graef, F., Hilger, T.H., Ferreira, L.G.R., Stahr, K., 2003b. An information system for land resources in Piauí and Ceará. In: Gaiser, T., Krol, M.S., Frischkorn, H., Araújo, J.C.de (Eds.), Global change and regional impacts: water availability and vulnerability of ecosystems and society in the semi-arid Northeast of Brazil, Springer, Berlin, pp. 267-278.

Grayson, R.B., Western, A.W., Chiew, F.H., Blöschl, G., 1997. Preferred states in spatial soil moisture patterns: local and nonlocal controls. Water Resources Research 33(12), 2897-2908.

Gresillon, J.M., Taha, A., 1998. Les zones saturées contributives en climat méditerranéen: condition d'apparition et influence sur les crues. Hydrological Sciences Journal 43(2), 267-282.

Goodrich, D.C., Lane, L.J., Shillito, R.M., Miller, S.N., Syed, K.H., Wollhiser, D.A., 1997. Linearity of basin response as a function of scale in a semiarid watershed. Water Resources Research 33(12), 2951-2965.

Güntner, A., 2002. Large-scale hydrological modelling in the semiarid North-East of Brazil, PIK Report No. 77, Potsdam Institute for Climate Impact Research, Potsdam, Germany, pp. 128; http://pub.ub.uni-potsdam.de/2002/0018/guentner.pdf.

Güntner, A., Bronstert, A., 2003. Large-scale hydrological modelling of a semi-arid environment: aspects of model sensitivity and uncertainty. In: Servat, E., Najem, W., Leduc, C., Shakeel, A. (Eds.), Hydrology of Mediterranean and Semiarid Regions, IAHS Publication No. 278, pp. 43-48.

Güntner, A., Krol, M.S., Araújo, J.C.de, Bronstert, A., 2004 Submitted for publication.

Gurtz, J., Baltensweiler, A., Lang, H., 1999. Spatially distributed hydrotope-based modelling of evapotranspiration and runoff in mountainous basins. Hydrological Processes 13(17), $2751-2768$.

Halm, D., 2000. Soil water balance in the semiarid Northeast of Brazil-characterisation, simulation, evaluation, and comparison of hydrological properties and processes in representative soils of the Picos region, Piauí. Hohenheimer Bodenkundliche Hefte, Heft 55. Universität Hohenheim, Institut für Bodenkunde und Standortslehre, Stuttgart, Germany, pp. 205.

Hayashi, I., 1995. Changing aspects of drought-de-ciduous vegetation in the semi-arid region of North-East Brazil. In: Nishizawa, T., Uitto, J. (Eds.), The Fragile Tropics of Latin America-Sustainable Management of Changing Environment, United Nations University Press, Tokyo, pp. 268-279.

IBGE, 1998. Censo Agropecuário 1995-1996, No. 11 (Ceará), Instituto Brasileiro de Geografia e Estatística, Rio de Janeiro, Brazil. 
Jarvis, P.G., 1976. The interpretation of leaf water potential and stomata conductance found in canopies in the field Philosophical Transactions of Royal Society of London, Series B 273, 593-610.

Karvonen, T., Koivusalo, H., Jauhiainen, M., Palko, J., Weppling, K., 1999. A hydrological model for predicting runoff from different land use areas. Journal of Hydrology 217, 253-265.

Kelliher, F.M., Leuning, R., Raupach, M.R., Shulze, E.D., 1995. Maximum conductances for evaporation from global vegetation types. Agricultural and Forest Meteorology 73, 1-16.

Kite, G.W., Kouwen, N., 1992. Watershed modeling using land classifications. Water Resources Research 28(12), 3193-3200.

Klausmeier, C.A., 1999. Regular and irregular patterns in semiarid vegetation. Science 284, 1826-1828.

Knudsen, J.A., Thomsen, A., Refsgaard, J.C., 1986. A semidistributed, physically based hydrological modelling system. Nordic Hydrology 17, 347-362.

Körner, C., 1994. Leaf diffusive conductances in the major vegetation types of the globe. In: Schulze, E.-D., Caldwell, M.M. (Eds.), Ecophysiology of Photosynthesis, Ecological Studies, vol. 100. Springer, Berlin, pp. 463-490.

Krysanova, V., Müller-Wohlfeil, D.I., Becker, A., 1998. Development and test of a spatially distributed hydrological/ water quality model for mesoscale watersheds. Ecological Modelling 106, 261-289.

Leavesley, G.H., Lichty, B.M., Troutman, L.G., Saindon, L.G., 1983. Precipitation-runoff modeling system: user's manual. USGS Water Resources Investigations Report 83-4238, USGS, Denver.

Manoel Filho, J., 2000. Recarga fluvial dos aquíferos nas bacias hidrográficas receptoras da transposição do Rio São Francisco. Anais do V Simpósio de Re-cursos Hídricos do Nordeste. ABRH (Associção Brasileira de Recursos Hídricos), Natal, vol. 1, pp. 112-121.

Martin, P.H., 1998. Land-surface characterization in climate models: biome-based parameter inference is not equivalent to local direct estimation. Journal of Hydrology 212/213, 287-303.

Martinez-Mena, M., Albaladejo, J., Castillo, V.M., 1998. Factors influencing surface runoff generation in a Mediterranean semiarid environment: Chicamo watershed, SE Spain. Hydrological Processes 12, 741-754.

Levantamento de recursos naturais-Projeto Radambrasil, vol. 21, Folhas SA 24 (Fortaleza), Ministerio das Minas e Energia, Secretaria Geral, Rio de Janeiro, Brazil.

Levantamento de recursos naturais-Projeto Radambrasil, vol. 23, Folhas SB 24/25 (Jaguaribe/Natal), Ministerio das Minas e Energia, Secretaria Geral, Rio de Janeiro, Brazil.

Merz, B., Plate, E.J., 1997. An analysis of the effects of spatial variability of soil and soil moisture on runoff. Water Resources Research 33(12), 2909-2922.

Merz, B., Bárdossy, A., Schiffler, G.R., 2002. Different methods for modelling the areal infiltration of a grass field under heavy precipitation. Hydrological Processes 16(7), $1383-1402$.
Milne, G., 1935a. Some suggested units for classification and mapping, particularly for East African soils. Soil Research of Berlin 4, 183-198.

Milne, G., 1935b. Composite units for the mapping of complex soil associations. Transactions of Third International Congress in Soil Science 1, 345-347.

Nash, J.E., Sutcliffe, J.V., 1970. River flow forcasting through conceptional models. Part I-A discussion of principles. Journal of Hydrology 10, 282-290.

Nicolau, J.M., Solé-Benet, A., Puigdefabregas, J., Gutierrez, L., 1996. Effects of soil and vegetation on runoff along a catena in semi-arid Spain. Geomorphology 14, 297-309.

Oldeman, L.R., van Engelen, V.W.P., 1993. A world soils and terrain digital database (SOTER)-An improved assessment of land resources. Geoderma 60, 309-325.

Patrick, E., 2002. Researching crusting soils: themes, trends, recent developments and implications for managing soil and water resources in dry areas. Progress in Physical Geography 26(3), $442-461$.

Perrolf, K., Sandström, K., 1995. Correlating land-scape characteristics and infiltration-A study of surface sealing and subsoil conditions in semi-arid Botswana and Tanzania. Geografiska Annaler Series A-Physical Geography 77A(3), $119-133$.

Peugeot, C., Esteves, M., Galle, S., Rajot, J.L., Vandervaere, J.P., 1997. Runoff generation processes: results and analysis of field data collected at the East Central Supersite of the HAPEX-Sahel experiment. Journal of Hydrology 188/189, 179-202.

Pfister, J.A., Malachek, J.C., 1986. Dietary selection by goats and sheep in a deciduous woodland of Northeastern Brazil. Pesquisa Agropecuária Brasileira 18, 1037-1043.

Puigdefabregas, J., Sanchez, G., 1996. Geomorphological implications of vegetation patchiness in semi-arid slopes. In: Anderson, M., Brooks, S. (Eds.), Advances in Hillslope Processes, Wiley, London, pp. 1027-1060.

Puigdefabregas, J., del Barrio, G., Boer, M.M., Gutierrez, L., Sole, A., 1998. Differential responses of hillslope and channel elements to rainfall events in a semi-arid area. Geomorphology 23(2-4), 337-351.

Puigdefabregas, J., Sole, A., Gutierrez, L., del Barrio, G., Boer, M., 1999. Scales and processes of water and sediment redistribution in drylands: results from the Rambla Honda field site in Southeast Spain. Earth-Science Reviews 48(1-2), $39-70$.

Rawls, W.J., Brakensiek, D.L., 1985. Prediction of soil water properties for hydrologic modeling. Watershed Management in the Eighties, ASCE, 293-299.

Reid, K.D., Wilcox, B.P., Breshears, D.D., MacDonald, L., 1999. Runoff and erosion in a Piñon-Juniper woodland: influence of vegetation patches. Soil Science Society of America Journal 63(6), 1869-1879.

Sandström, K., 1996. Hydrochemical deciphering of streamflow generation in semi-arid East Africa. Hydrological Processes 10, $703-720$.

Sampaio, E.V.S.B., Araújo, E.L., Salcedo, I.H., Tiessen, H., 1998. Regeneração da vegetação de caatinga após corte e queima, em 
Valentin, C., d'Herbès, J.M., 1999. Niger tiger bush as a natural water harvesting system. Catena 37, 231-256.

Serra Talhada, PE. Pesquisa Agropecuária Brasileira 33(5), $621-632$.

Schulla, J., 1997. Hydrologische Modellierung von Flussgebieten zur Abschätzung der Folgen von Klimaänderungen, Zürcher Geographische Schriften, No. 69, ETH Zürich (Swiss Federal Institute of Technology), Zürich, Switzerland, p. 161, (in German).

Schulze, E.D., Kelliher, F.M., Körner, C., Lloyd, J., Leuning, R., 1994. Relationships among maximum stomatal conductance, ecosystem surface conductance, carbon assimilation rate and plant nitrogen nutrition: a global ecology scaling exercise. Annual Reviews of Ecology System 25, 629-660.

Schumann, A.H., Funke, R., Schultz, G.A., 2000. Application of a geographic information system for conceptual rainfall-runoff modelling. Journal of Hydrology 240, 45-61.

Seyfried, M.S., Wilcox, B.P., 1995. Scale and the nature of spatial variability-field examples having implications for hydrologic modeling. Water Resources Research 31(1), 173-184.

Shuttleworth, W.J., Wallace, J.S., 1985. Evaporation from sparse crops-an energy combination theory. Quarterly Journal of Royal Meteorological Society 111, 839-855.

Stewart, J.B., 1988. Modelling surface conductance of pine forest. Agricultural and Forest Meteorology 43, 19-37.

SUDENE, 1972. Mapa exploratório-reconhecimento de solos do Estado do Ceará (1:600.000). Superintendencia do Desenvolvimento do Nordeste, Recife, Brazil.

SUDENE, 1973. Levantamento exploratório-reconhecimento de solos do Estado do Ceará, vol. I + II. Série Pedolgia No. 16, Superintendencia do Desenvolvimento do Nordeste, Recife, Brazil, pp. 301 and 502.

Tague, C.L., Band, L.E., 2001. Evaluating explicit and implicit routing for watershed hydro-ecological models of forest hydrology at the small catchment scale. Hydrological Processes $15,1415-1439$.

Tiessen, H., Feller, C., Sampaio, E.V.S.B., Garin, P., 1998. Carbon sequestration and turnover in semi-arid savannas and dry forest. Climate Change 40, 105-117.

Tomasella, J., Hodnett, M.G., 1997. Estimating unsaturated hydraulic conductivity of Brazilian soils using soil-water retention data. Soil Science 162(10), 703-712.

Torri, D., Colica, A., Rockwell, D., 1994. Preliminary study of erosion mechanisms in a biancan badland (Tuscany, Italy). Catena 23, 281-294.

Uhlenbrook, S., Leibundgut, Ch., 2002. Process-oriented catchment modelling and multiple-response validation. Hydrological Processes 16, 423-440.
Van de Giesen, N.C., Stomph, T.J., De Ridder, N., 2000. Scale effects of Hortonian overland flow and rainfall-runoff dynamics in a West African catena landscape. Hydrological Processes 14, $165-175$.

Van Genuchten, M.T., 1980. A closed-form equation for predicting the hydraulic conductivity of unsaturated soils. Soil Science Society of America Journal 44, 892-898.

Wielemaker, W.G., de Bruin, S., Epema, G.F., Veldkamp, A., 2001. Significance and application of the multi-hierarchical landsystem in soil mapping. Catena 43, 15-34.

Wigmosta, M.S., Vail, L.W., Lettenmaier, D.P., 1994. A distributed hydrology-vegetation model for complex terrain. Water Resources Research 30(6), 1665-1679.

Wilcox, B.P., Newman, B.D., Brandes, D., Davenport, D.W., Reid, K., 1997. Runoff from a semiarid ponderosa pine hillslope in New Mexico. Water Resources Research 33(10), 2301-2314.

Williams, J.R., Jones, C.A., Dyke, P.T., 1983. The EPIC model and its application. In: ICRISAT-IB-SNAT-SYS, (Ed.), Proceedings of ICRISAT-IBSNAT-SYS Symposium on Minimum Data Sets for Agrotechnology Transfer, Hyderabad, India, pp. 111-121.

Wood, E.F., Lettenmaier, D.P., Zartarian, V.G., 1992. A landsurface hydrology parameterization with subgrid variability for general circulation models. Journal of Geophysical Research 97(D3), 2717-2728.

Wooldridge, S.A., Kalma, J.D., 2001. Regional-scale hydrological modelling using multiple-parameter landscape zones and a quasi-distributed water balance model. Hydrology and Earth System Sciences 5(1), 59-74.

Woolhiser, D.A., Smith, R.E., Giraldez, J.V., 1996. Effects of spatial variability of saturated hydraulic conductivity on Hortonian overland flow. Water Resources Journal 190, $49-56$.

Yair, A., Lavee, H., 1985. Runoff generation in arid and semi-arid zones. In: Anderson, M.G., Burt, T.P. (Eds.), Hydrological Forecasting, Wiley, New York, pp. 183-220.

Ye, W., Bates, B.C., Viney, N.R., Sivapalan, M., Jakeman, A.J., 1997. Performance of conceptual rainfall-runoff models in lowyielding ephemeral catchments. Water Resources Research 33(1), 153-166.

Zhao, R.J., Zhuang, Y.-L., Fang, L.-R., Liu, X.-R., Zhang, Q.-S., 1980. The Xinanjiang model, IAHS Publication No. 129, 129., pp. 351-356.
2449

2450

2451

2452

2453

2454

2455

2456

2457

2458

2459

2460

2461

2462

2463

2464

2465

2466

2467

2468

2469

2470

2471

2472

2473

2474

2475

2476

2477

2478

2479

2480

2481

2482

2483

2484

2485

2486

2487

2488

2489

2490

2491

2492

2493

2494

2495

2496 